\title{
İlgili Çalışmalardan Hareketle Suriyelilere Türkçe Öğretiminde Karşılaşılan Sorunlar Yakup ALAN*
}

• Geliş Tarihi: 04.06.2020 • Kabul Tarihi: 03.11.2020 • Çevrimiçi Yayın Tarihi: 04.11.2020

\section{$\ddot{O} z$}

$\mathrm{Bu}$ araştırmanın amacı, Suriyelilere Türkçe öğretiminde karşılaşılan sorunları ilgili makalelerden hareketle incelemektir. Bu doğrultuda yapılan tarama sonucunda Suriyelilere Türkçe öğretiminde yaşanan sorunları ele alan 64 makale incelenmiştir. Meta-sentez yönteminin kullanıldığı çalışmada verilerin çözümlenmesinde içerik analizi yöntemi kullanılmıştır. İncelenen makalelerin genel eğilimleri ve makalelerde ele alınan sorunlar sınıflandırılmış ve grafikler/tablolar hâlinde sunulmuştur. Yapılan analiz sonucunda makalelerde daha çok olgubilim deseninin kullanıldığı, örneklem olarak öğretmenlerin, veri toplama aracı olarak görüşme yönteminin ve analiz yöntemlerinden de içerik analizinin çoğunlukla kullanıldığı belirlenmiştir. Ayrıca makalelerde; materyal sorunlarına, Türkçenin dil özelliklerinden kaynaklanan sorunlara, duyuşsal sorunlara, öğretici kaynaklı sorunlara, program sorunlarına, öğrenme ortamından kaynaklanan sorunlara, öğrenme alanlarıyla ilgili sorunlara, aile ve çevre kaynaklı sorunlara değinildiği tespit edilmiştir.

Anahtar sözcükler: Türkçe öğretimi, Suriyelilere Türkçe öğretimi, Suriyelilere Türkçe öğretiminde sorunlar, literatür incelemesi.

\section{Atıf:}

Alan, Y. (2021). İlgili Çalışmalardan Hareketle Suriyelilere Türkçe Öğretiminde Karşılaşılan Sorunlar. Pamukkale Üniversitesi Eğitim Fakültesi Dergisi, 52, 119-146.doi:10.9779/pauefd.748162.

\footnotetext{
* Dr. Öğr. Üyesi, Kilis 7 Aralık Üniversitesi, alanyakup@ggmail.com, https://orcid.org/0000-0002-9888-1357
} 


\section{Giriş}

Türkçenin yabancı dil olarak öğretiminin başlangıcı, birçok araştırmada Divanü Lügati'tTürk'le başlatılmış olsa da Biçer'e (2012) göre Hunlarda, Türkçenin yabancı dil olarak öğretildiğine dair izler bulunmaktadır. Bu bilgi aslında Türkçenin yabancı dil olarak öğretilmesiyle ilgili faaliyetlerin ne kadar köklü bir geçmişe sahip olduğunun göstergesidir. Hunlar döneminde başlayan bu süreç aradan geçen her bir yılda gelişme kaydederek içinde bulunduğumuz yüzyıla kadar gelmiştir. Süreç içinde Türkçenin yabancı dil olarak öğretilmesi faaliyetleri ile ilgilenen kurum ve kişi sayısı ciddi anlamda artmış ve hem yurt dışında hem de yurt içinde bu misyonu üstlenen birimler açılmıştır. Günümüzde ise Türkçenin yabancı dil olarak öğretimi ile ilgili faaliyetler yurt içinde neredeyse tüm üniversiteler bünyesinde kurulan Türkçe/dil öğretim merkezleri, halk eğitim merkezleri, geçici eğitim merkezleri veya özel eğitim kurumları tarafından yürütülmektedir.

Son yıllarda ise Suriye'de yaşanan iç karışıklıklardan dolayı ülkemize milyonlarca Suriyelinin gelmesi, onlara yönelik Türkçe öğretim faaliyetlerinde de çok hızlı bir artışa sebep olmuştur. Birçok kurum ve kuruluş Suriyelilere Türkçe öğreterek onların entegrasyon ve eğitim süreçlerine dahil olabilmelerini sağlamak amaciyla bir dizi faaliyetler yürütmeye başlamıştır. Üniversitelere bağlı Türkçe/dil öğretim merkezleri, Millî Eğitim Bakanlığı, Yurtdışı Türkler ve Akraba Topluluklar Başkanlığı, uluslararası/ulusal kuruluş ve vakıflar, halk eğitim merkezleri ve özel eğitim kurumları bu alanda faaliyet yürüten kurum ve kuruluşlardan bazılarıdır.

Hem yurt dişında hem de yurt içinde yürütülen Türkçe öğretimi faaliyetlerinde çeşitli sorunların yaşandığı bilinmektedir. Bu sorunlardan bazıları; Türkçe öğretim programlarından kaynaklanan sorunlar, materyal eksikliği, yabancılara Türkçe öğretiminde kullanılan yöntem sorunları, alfabe farklılığı, Türkçenin yapısal farklılıklarından kaynaklanan sorunlar ve eğiticilerden kaynaklanan sorunlar şeklinde verilebilir (Açık, 2008; Alyılmaz, 2010; Candaş Karababa, 2009; Demirel ve Şahinel, 2006; Durmuş, 2013; Er, Biçer ve Bozkırlı, 2012; Okur, 2013).

Suriyelilere Türkçe öğretimi faaliyetlerinin başlamasıyla birlikte zaten yabancılara Türkçe öğretiminde karşılaşılan sorunların yanında farklı sorunlar da ortaya çıkmaya başlamıştır. Özellikle çok sayıda öğrencinin olması bu sorunların görülmesine neden olan etkenlerin başında gelmektedir. Ayrıca Suriyeli öğrenciler için geçici eğitim merkezlerinin açılması veya bu öğrencilerin Bakanlığa bağlı okullarda eğitim almaya başlaması da Türkçe öğretiminde yaşanan sorunlara farklı bir boyut eklemiştir. Burak ve Amaç (2020) da ilkokul 
eğitimi alan Suriyeli öğrencilerin durumunu ortaya koydukları çalışmalarında öğretmenlerin donanım eksikliğinden, öğretim programlarının yetersizliğinden ve eğitim sisteminden kaynaklı birçok sorunun yaşandığından bahsetmektedir. Ortaya çıkan bu sorunlar öğretmenlerin Türkçe öğretirken de olumsuz etkilenmelerine neden olmaktadır. Bu nedenlerle Suriyelilere Türkçe öğretiminde yaşanan sorunların tespiti, bu sorunların giderilmesi ve daha nitelikli Türkçe öğretim faaliyetlerinin yürütülmesi açısından oldukça önemlidir.

Alanyazında Türkçenin yabancı dil olarak öğretilmesinde yaşanan sorunlarla ilgili çalışmaların eğilimlerini belirlemeye yönelik araştırmalar mevcuttur (Biçer ve Alan, 2019; Er vd., 2012; Türkben, 2018). Ayrıca Suriyelilerin eğitim sorunlarını inceleyen alanyazın taraması niteliğinde çalışma da mevcuttur (Tunga, Engin ve Çağıltay, 2020).

Suriyelilere Türkçe öğretiminde yaşanan sorunları ele alan veya bu sorunlara değinen çalışmaların sayısı oldukça fazladır. Alanyazın incelendiğinde bu çalışmalarda ortaya çıkan sorunların genel olarak materyal sorunları (Beyhan ve Epçaçan, 2018; Boylu ve Işı1, 2019; Bulut, Kanat Soysal ve Gülçiçek, 2018; Doğan ve Ateş, 2018; Gözübüyük Tamer, 2020); Türkçenin dil özelliklerinden dolayı yaşanan sorunlar (Demirci, 2015; Gün ve Ağırman, 2018; Koçoğlu ve Yanpar Yelken, 2018; Moralı, 2018; Şengül, 2014); duyuşsal sorunlar (Bozkırlı, Er ve Alyılmaz, 2018; Dilek, Boyaci ve Yaşar, 2018; Erdem, 2016; Yı1dız, 2016); eğiticilerden kaynaklanan sorunlar (Eyüp, Aslan ve Cevher, 2017; Özkale ve Yanpar Yelken, 2020; Pilancı, Çalışır Zenci, Saltık ve Yaşar, 2020); müfredat kaynaklı sorunlar (Aykırı, 2017; Şen ve Solak, 2019; Ünal, Taşkaya ve Ersoy, 2018); sınıf yönetimi ve öğretim ortamından kaynaklanan sorunlar (Balkar, Şahin ve Işıklı Babahan, 2016; Kardeş ve Akman, 2018); öğrenme alanlarında yaşanan sorunlar (Demirgüneş, 2017; Kan ve Utlu, 2017; Kara, 2010); aile ve çevreden kaynaklanan sorunlar (Güngör ve Şenel, 2018) olarak sıralanabilir. Suriyelilere Türkçe öğretiminde yaşanan bu sorunların belirlenmesi ve bunlara yönelik çözüm önerilerinin sunulması oldukça önemlidir. Çünkü Türkçenin daha sistemli ve işlevsel öğretilebilmesi için yaşanan sorunların en aza indirilmesi gerekmektedir. Bu nedenle hem sorunları tespit eden hem de bu sorunları çözmeye yönelik çalışma sonuçlarını barındıran araştırmaların değeri tartışılmaz bir gerçektir. Suriyelilere Türkçe öğretiminde yaşanan sorunları tespit etmeye veya çözüm üretmeye yönelik çok sayıda araştırma olsa da bu çalışmaların genel eğilimlerini belirleyen herhangi bir araştırma yoktur. Suriyelilere Türkçe öğretiminde yaşanan sorunlara değinen çalışmaların genel eğilimlerini ortaya çıkarması ve belirlenen sorunları genel bir bakış açısıyla görmeyi sağlaması açısından araştırmanın alanyazına katkı sunacağı düşünülmektedir. 


\section{Amaç}

$\mathrm{Bu}$ araştırmanın amacı, Suriyelilere Türkçe öğretiminde yaşanan sorunları, ilgili çalışmalar doğrultusunda ele almaktır. Bu bağlamda araştırmada aşağıdaki sorulara cevap aranmıştır:

1. İncelenen araştırmalarda kullanılan araştırma modellerinin/desenlerinin dağılımı nasildir?

2. İncelenen araştırmalarda örneklem grubunun dağılımı nasıldır?

3. İncelenen araştırmalarda kullanılan veri toplama araçları nelerdir?

4. İncelenen araştırmalarda kullanılan veri analiz yöntemleri nelerdir?

5. İncelenen araştırmalarda, Suriyelilere Türkçe öğretiminde yaşanan hangi sorunlar ele alınmaktadır?

\section{Yöntem}

Araştırmanın bu bölümünde; araştırmanın modeli, çalışma grubu, verilerin toplanması ve veri analiz yöntemi hakkında bilgi verilmiştir.

\section{Araşturma Deseni}

Suriyelilere Türkçe öğretiminde yaşanan sorunları ele almaya yönelik hazırlanmış makalelerin genel eğilimlerini ve makalelerde ele alınan sorunları değerlendirmeyi amaçlayan bu araştırmada meta-sentez modeli kullanılmıştır. Çalık ve Sözbilir'e (2014) göre meta-sentez araştırmalarında belirli bir alanda hazırlanan araştırmaların ortak ve farklı yönleri ele alınır ve ortaya bir başvuru kaynağı çıkarılır. Bu araştırmada da Suriyelilere Türkçe öğretiminde yaşanan sorunların yansıtılması amacıyla bu yöntem kullanılmıştır.

\section{Verilerin Toplanması ve Araştırmaların Dâhil Edilme Kriterleri}

Araştırma kapsamında, Suriyelilere Türkçe öğretiminde yaşanan sorunları ele alan araştırmaları belirlemek amacıyla Google Akademik arama motoru, Yandex arama motoru, Ulakbim, Sobiad, Academia ve ResearchGate veri tabanlarında tarama yapılmıştır. Taramalar; "Suriyelilere Türkçe öğretimi, Suriyelilere Türkçe öğretiminde sorunlar, yabancilara Türkçe öğretiminde yaşanan sorunlar, mültecilerin eğitim sorunları" şeklindeki anahtar ifadelerle gerçekleştirilmiştir. Taramalar hem Türkçe hem de İngilizce olarak yapılmıştır.

Yapılan taramalar sonucunda çok sayıda çalışmaya ulaşılmış ve bunlardan sorunlarla ilgili olmayanlar elenmiş ve 90 çalışma kalmıştır. Bu çalışmalarda; 2010-2020 yılları arasında yayımlanmış olması, makale olması ve Suriyelilere Türkçe öğretiminde yaşanan sorunlara 
değinmesi şartları aranmıştır. Makale niteliği taşımayan, çalışmanın Suriyelilere Türkçe öğretimine yönelik olduğunu belirtmeyen, Araplara Türkçe öğretiminde yaşanan sorunlara değinmesine rağmen yine Suriyelilerle ilgili olduğuna dair bilgi bulunmayan 26 çalışma elenmiş ve 64 makale araştırmaya dâhil edilmiştir. Araştırmaya dâhil edilen çalışmaların yazar sayısı, yayımlanma yılları ve yayın dilleri ile ilgili bilgiler Grafik 1, Grafik 2 ve Grafik 3'te verilmiştir:

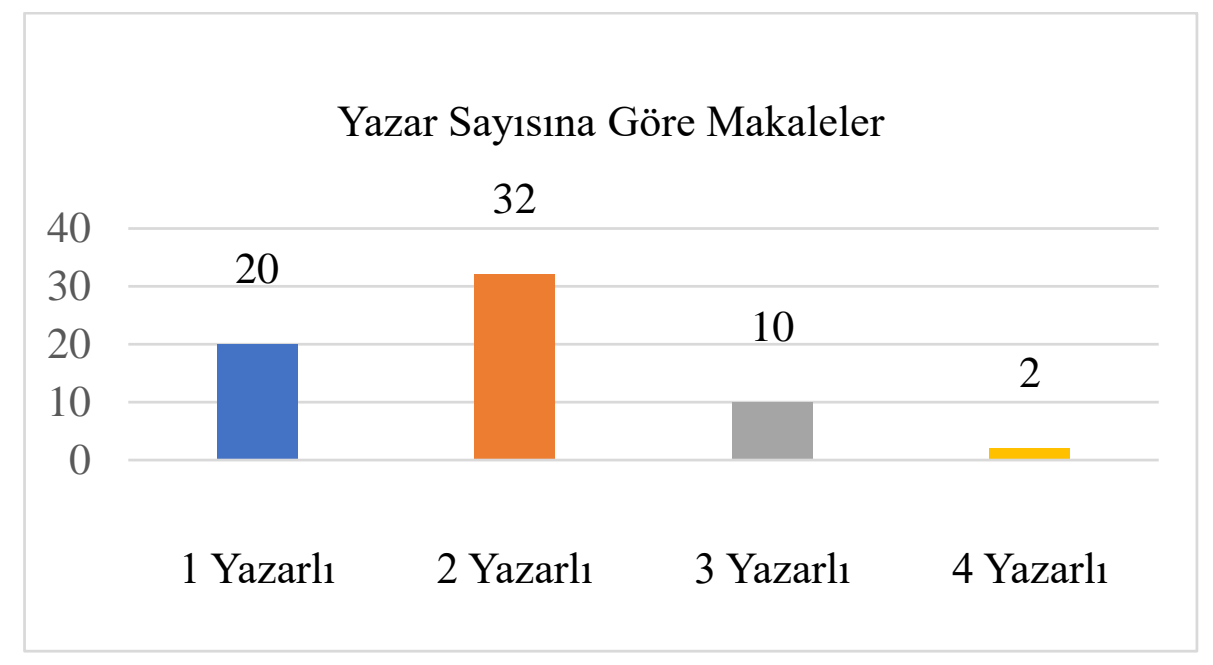

Grafik 1. Makalelerin Yazar Sayısı

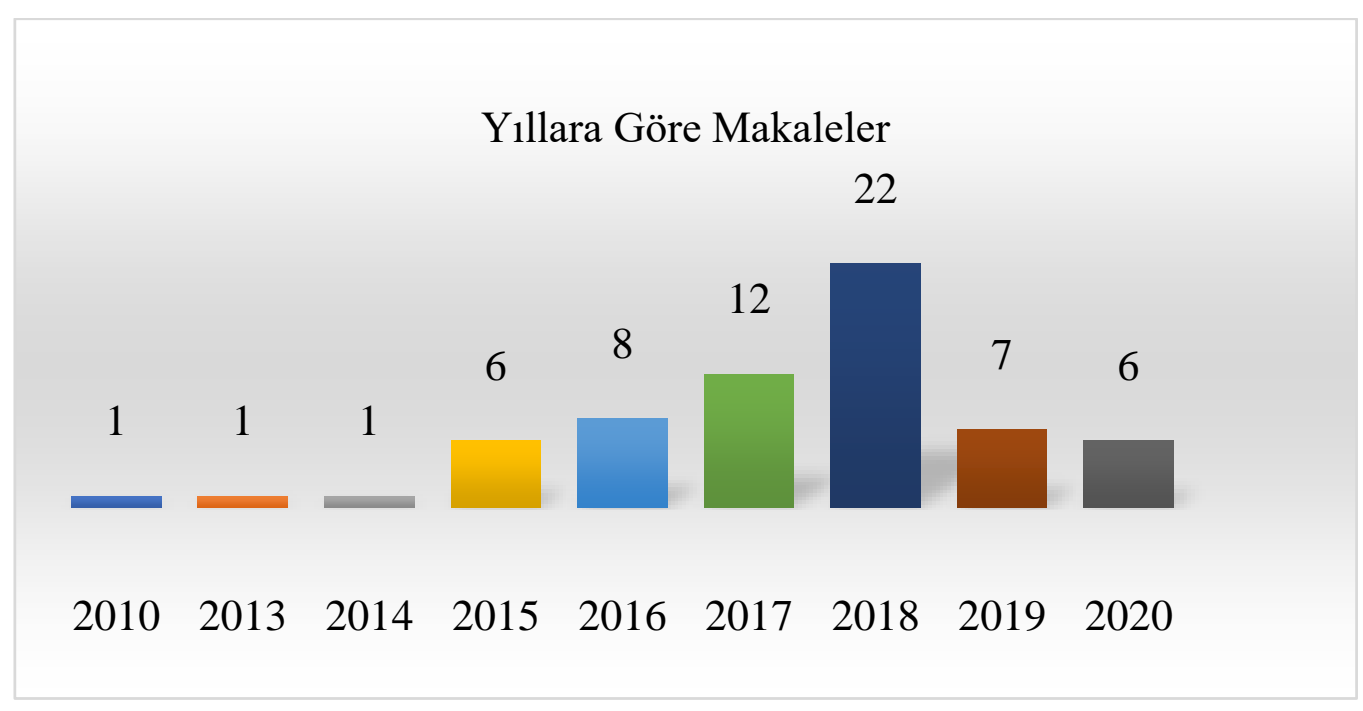

Grafik 2. Makalelerin Yıllara Göre Dă̆ılımı 


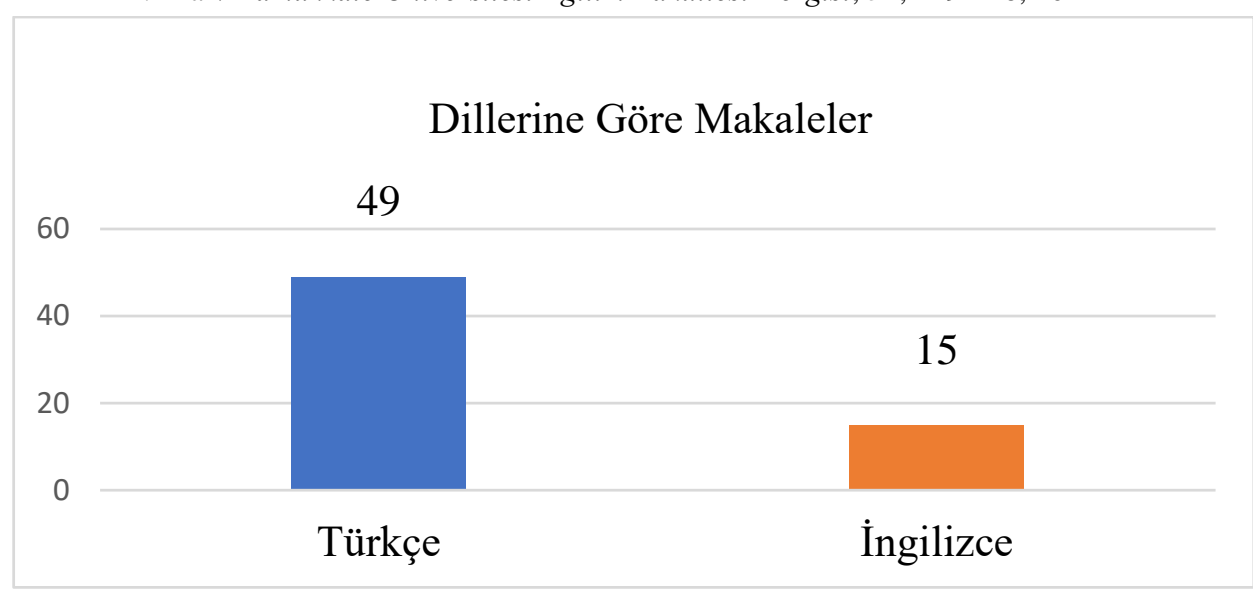

\section{Grafik 3. Makalelerin Dillerine Göre Dă̆ılımı}

\section{Verilerin Analizi}

Suriyelilere Türkçe öğretiminde yaşanan sorunları ele alan makalelerin analizinde, içerik analizi yöntemi kullanılmıştır. İçerik analizinde incelenen makalelerin öncelikli olarak genel eğilimleri (araştırma modeli/deseni, örneklem grubu, yayım yılı, yazar sayısı, yayım dilleri, veri toplama araçları ve veri analiz yöntemleri) belirlenmiştir. Daha sonra makalelerde ele alınan sorunlar sınıflandırılmış ve tablolar hâlinde sunulmuştur.

Makaleler üzerinde araştırmacı dışında başka bir uzman da örneklemden rastgele seçilen 8 makale üzerinde inceleme yapmıştır. Ortaya çıkan verilerin güvenirliğini belirleyebilmek için inceleyiciler arasındaki uyum belirlenmiştir. Miles ve Huberman'in (1994) formülü kullanılarak yapılan hesaplama sonucunda inceleyiciler arası uyumun .86 olduğu tespit edilmiştir. Araştırmada veriler grafik, tablo ve frekanslardan yararlanılarak sunulmuştur.

\section{Bulgular}

\section{İncelenen Makalelerin Yöntemleriyle İlgili Bulgular}

Araştırmanın bu bölümünde incelenen makalelerin yöntem kısmını oluşturan araştırma modeli/deseni, örneklem, veri toplama araçları ve veri analiz yöntemleri hakkında bilgiler sunulmuştur.

İncelenen makalelerin araştırma modelleri/desenleri ile ilgili bilgiler Grafik 4'te sunulmuştur: 


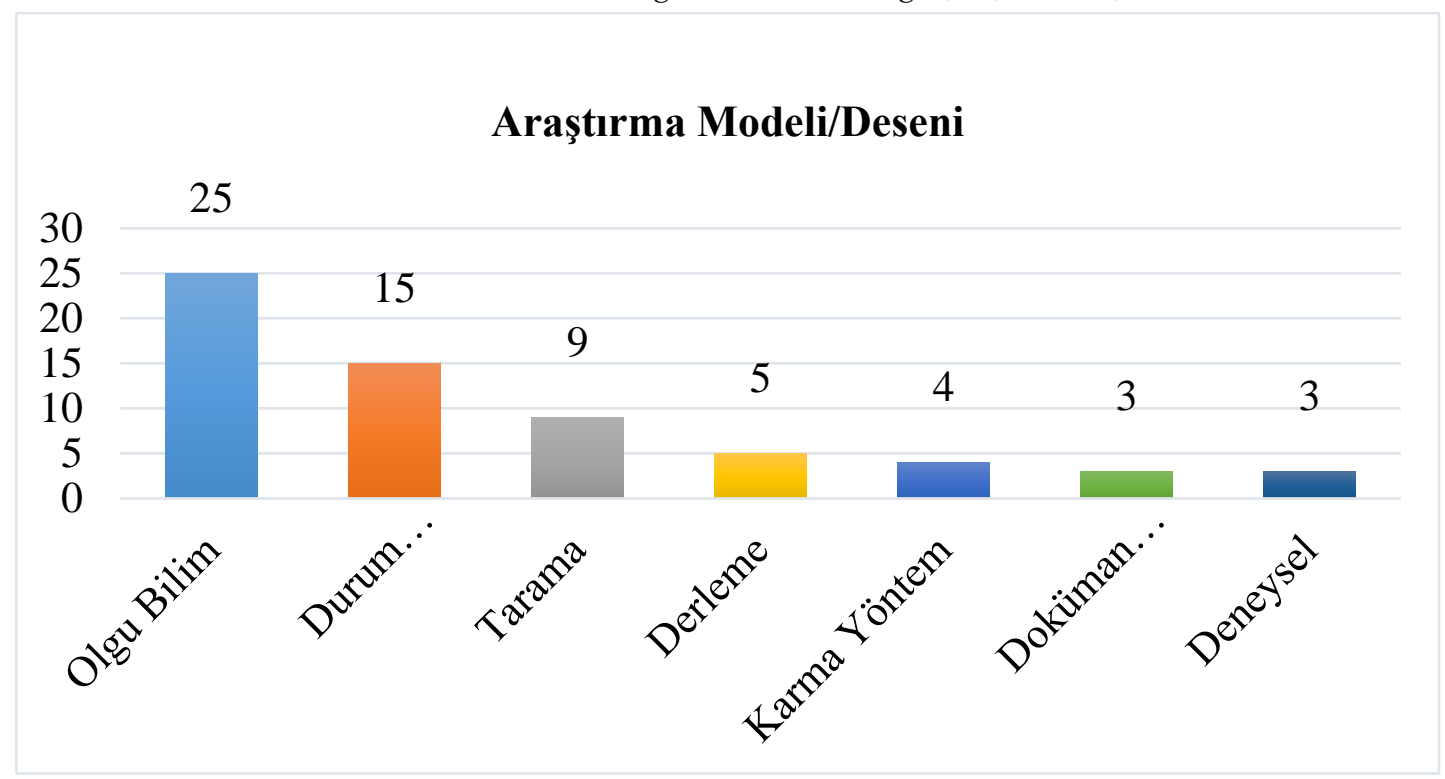

Grafik 4. Makalelerin Araştırma Modellerine/Desenlerine Göre Dă̆ılımı

Grafik 4'e göre; Suriyelilere Türkçe öğretiminde yaşanan sorunların araştırılmasında en çok kullanılan model/desen olgu bilimdir. 25 araştırmada bu desen kullanılmıştır. Bu deseni durum çalışması, tarama, derleme çalışmaları, karma yöntem, doküman incelemesi, deneysel model ve betimsel model takip etmektedir.

İncelenen makalelerin örneklemlerine ilişkin bulgular Grafik 5'te sunulmuştur.

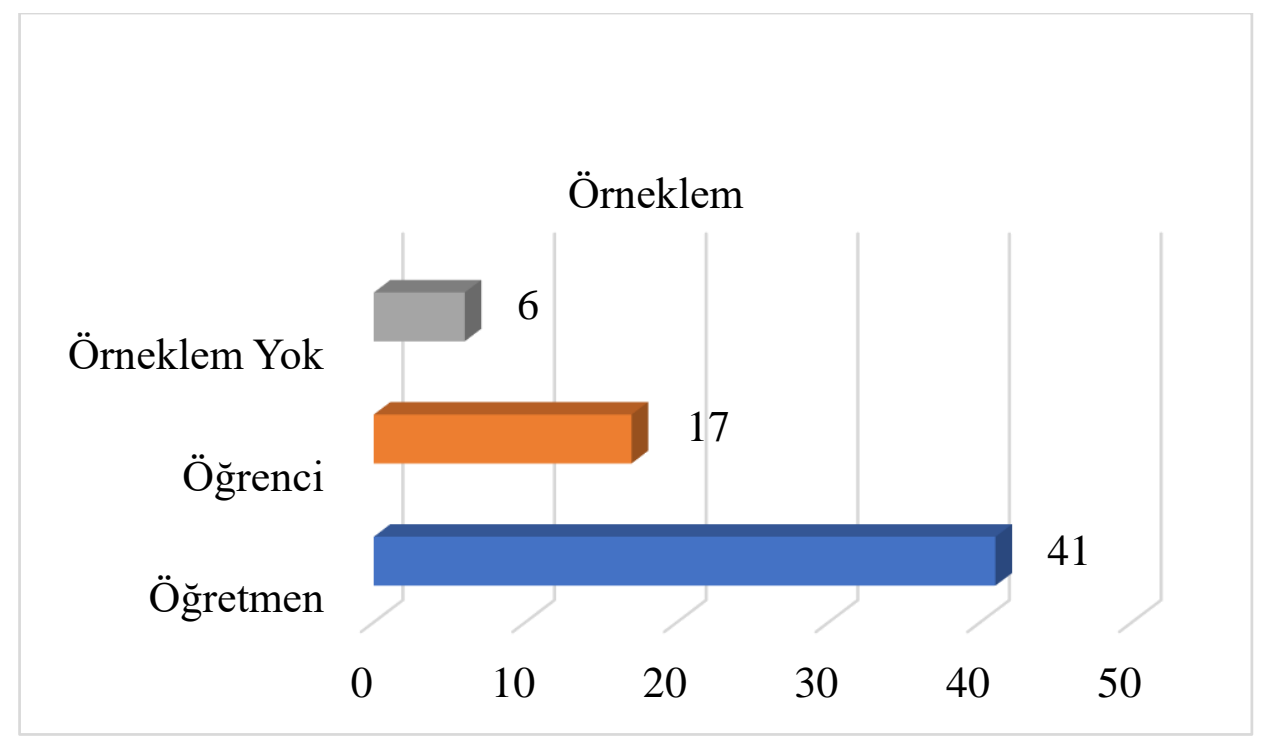

\section{Grafik 5. Makalelerin Örneklemlerine Göre Dă̆ılımı}

Grafik 5 incelendiğinde Suriyelilere Türkçe öğretiminde yaşanan sorunlara yönelik hazırlanan araştırmaların çoğunun (41) örnekleminin öğretmenlerden oluştuğu görülmektedir. Araştırmalar incelendiğinde ilkokul, ortaokul ve lise öğretmenlerinin, PİKTES projesi kapsamında görev yapan öğretmenlerin, Türkçe/dil öğretim merkezlerinde görev yapan 
öğretim elemanlarının veya halk eğitim merkezlerindeki öğretmenlerin konuyla ilgili görüşlerinin alındığg görülmektedir. 17 çalışmada ise yaşanan sorunlarla ilgili öğrenci görüşü alındığı tespit edilmiştir. Ayrıca 6 çalışmada da örneklem hakkında bilgi verilmemiştir.

İncelenen makalelerin veri toplama araçlarıyla ilgili bilgiler Grafik 6'da verilmiştir:

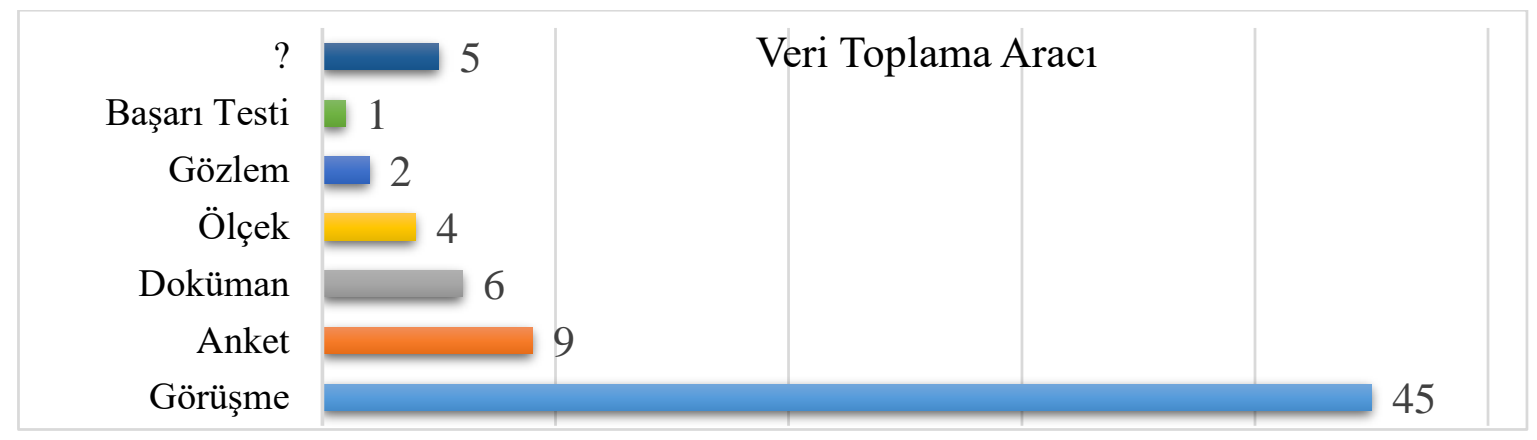

\section{Grafik 6. Makalelerin Veri Toplama Araçlarının Dağılımı}

İncelenen makalelerin veri toplama araçlarına bakıldığında büyük kısmında verilerin görüşme yöntemiyle (45) elde edildiği görülmektedir. Anket (9), doküman (6), ölçek (4), gözlem (2) ve başarı testi (1) de kullanılan diğer veri toplama araçlarıdır. 5 araştırma ise derleme çalışması olduğu için veri toplama araçları hakkında bilgi verilmemiştir.

İncelenen makalelerin veri analiz yöntemlerine ilişskin bulgular Grafik 7'de verilmiştir:

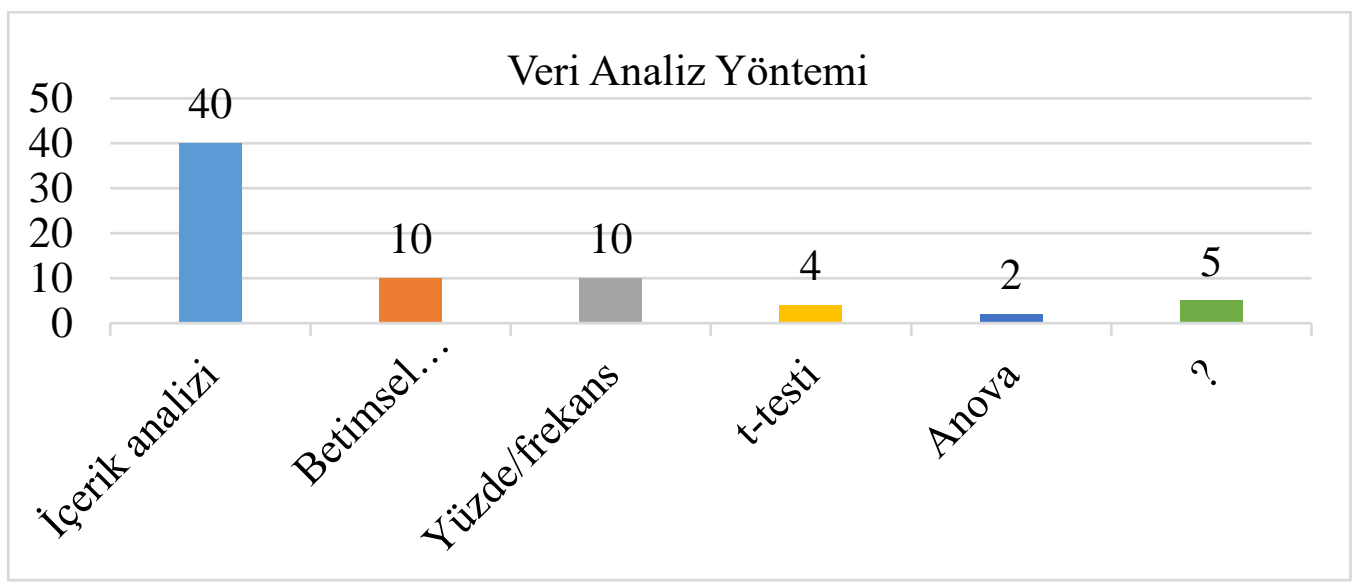

Grafik 7. Makalelerin Veri Analiz Yöntemlerinin Dă̆ılımı

Suriyelilere Türkçe öğretiminde yaşanan sorunlara ilişkin makaleler incelendiğinde çoğunda elde edilen verilerin analizi için içerik analizi (40) yöntemimin, betimsel analiz (10) ve yüzde/frekans (10) yöntemlerinin kullanıldığı görülmektedir. T-testi ve Anova da kullanılan diğer yöntemlerdir. Derleme araştırmalarında (5) ise veri analiz yöntemi hakkında bilgi bulunmamaktadır. 
Araştırmanın bu bölümünde de incelenen makalelerde tespit edilen sorunlar; Materyal Sorunları, Türkçenin Dil Özelliklerinden Kaynaklanan Sorunlar, Duyuşsal Sorunlar, Öğretmenden Kaynaklanan Sorunlar, Müfredat Kaynaklı Sorunlar, Sınıf Yönetiminden Kaynaklı Sorunlar, Öğrenme Alanlarıyla İlgili Sorunlar, Öğretim Ortamından Kaynaklanan Sorunlar, Aile ve Çevreden Kaynaklanan Sorunlar şeklinde sınıflandırılmış ve tablolar hâlinde sunulmuştur. Ayrıca tablolarda frekansı ortaya çıkarması amacıyla sorunun geçtiği çalışmanın kodu da yazılmıştır.

Suriyelilere Türkçe öğretiminde yaşanan materyal kaynaklı sorunlarla ilgili bulgular Tablo 1'de sunulmuştur:

Tablo 1. Suriyelilere Türkçe Öğretiminde Yaşanan Materyal Sorunları

\begin{tabular}{ll}
\hline & $f$ \\
\hline Materyal (kaynak) eksikliğinden kaynaklanan sorunlar & 15 \\
Kitapların yetersiz olmasından kaynaklanan sorunlar & 10 \\
Kitapların seviyeye uygun olmamasından kaynaklanan sorunlar & 3 \\
Materyallerin içeriksel yetersizliğinden kaynaklanan sorunlar & 2 \\
Materyallerin seviyeye uygun olmamasından kaynaklanan sorunlar & 2 \\
Kitapların fiziksel yetersizliğinden kaynaklanan sorunlar & 2 \\
Öğretmen kılavuz kitabının olmamasından kaynaklanan sorunlar & 1 \\
Kitapların belli becerilere yönelik olmasından kaynaklanan sorunlar & 1 \\
\hline
\end{tabular}

Tablo 1'de; Suriyelilere Türkçe öğretiminde yaşanan sorunları ortaya çıkarmak amacıyla hazırlanan makalelerde tespit edilen materyal kaynaklı sorunlar yer almaktadır. Araştırmalara göre materyalden kaynaklanan en büyük sorun materyal eksikliği yaşanmasıdır. 15 araştırmada yer aldığı tespit edilen bu sorunu kitapların yetersiz olması (10), kitapların seviyeye uygun olmaması (3), mevcut materyallerin içeriksel ve fiziksel yetersizlikleri (2), materyallerin seviyeye uygun olmaması (2), kitapların fiziksel yetersizlikleri (2), kitapların belli becerilere ağırlık vermesi (1) ve öğretmen kılavuz kitabının olmaması (1) takip etmektedir.

Türkçenin dil özelliklerinden ve yanlış öğrenmeden kaynaklı sorunlara ilişkin bulgular Tablo 2'de verilmiştir: 
Tablo 2. Türkçenin Dil Özelliklerinden ve Yanlış Öğrenmeden Kaynaklı Sorunlar

\begin{tabular}{lc}
\hline & $f$ \\
\hline Alfabe farklılı̆̆ı & 17 \\
Türkçenin yapısal farklılıkları & 11 \\
Ünlü harflerin yanlış kullanılması & 4 \\
Harflerin karıştırılması & 3 \\
Büyük harflerin yanlış kullanılması & 1 \\
Çok fazla kural olması & 1 \\
Noktalama işaretlerinin kullanılmaması & 1 \\
Ünsüz harflerin yanlış kullanılması & 1 \\
\hline
\end{tabular}

Tablo incelendiğinde, araştırmalarda Türkçenin dil özelliklerinden ve yanlış öğrenmelerden dolayı yaşandığı tespit edilen sorunların başında alfabe farklılığının geldiği görülmektedir. 17 çalışmada tespit edilen bu sorunu Türkçenin yapısal farklılığ1 (11), ünlü harflerin yanlış kullanılması (4), harflerin karıştırılması (3), büyük harflerin yanlış kullanılması (1), çok fazla kural olması (1), noktalama işaretlerinin kullanılmaması (1) ve ünsüz harflerin yanlış kullanılması (1) takip etmektedir.

Suriyelilere Türkçe öğretiminde yaşanan duyuşsal sorunlarla ilgili tespit edilen bulgulara Tablo 3 'te yer verilmiştir:

Tablo 3. Suriyelilere Türkçe Öğretiminde Yaşanan Duyuşsal Sorunlar

\begin{tabular}{lc}
\hline & $f$ \\
\hline Motivasyon eksikliği & 12 \\
Türkçeye karşı olumsuz tutum & 5 \\
Psikolojik sorunlar & 4 \\
Direnç & 3 \\
Kaygi & 3 \\
Ön yargı & 3 \\
Benliği kaybetme korkusu & 1 \\
Öz güven eksikliği & 1 \\
\hline
\end{tabular}


İncelenen çalışmalara göre Suriyelilere Türkçe öğretiminde yaşanan duyuşsal sorunların başında öğrencilerin motivasyon eksiklikleri gelmektedir. 12 araştırmada bu soruna yer verilmiştir. Öğrencilerin Türkçeye karşı olumsuz tutum sahibi olmaları (5) da diğer önemli duyuşsal sorundur. Psikolojik sorunlar (4), Türkçe öğrenmeye karşı direnç (3), kaygı (3), ön yargı (3), benliği kaybetme korkusu (1) ve öz güven eksikliği (1) de ortaya çıkarılan diğer duyuşsal sorunlardır.

Suriyelilere Türkçe öğretiminde yaşanan öğretmen kaynaklı sorunlarla ilgili bulgular Tablo 4'te verilmiştir:

Tablo 4. Suriyelilere Türkçe Öğretiminde Yaşanan Öğretmen Kaynaklı Sorunlar

\begin{tabular}{ll}
\hline & $f$ \\
\hline Alan bilgisine hâkim olmama & 20 \\
Yanlış yöntem teknik kullanma & 9 \\
Aldıkları eğitimlerin yetersiz olması & 7 \\
Öğretmenlerin ayrı bir eğitim almaması & 4 \\
Öz yeterlik eksikliği & 2 \\
Programlardan haberinin olmaması & 2 \\
Dil bilgisi odaklı eğitim yapılması & 1 \\
Tecrübe eksikliği & 1 \\
Uzman olmayan kişilerin Türkçe öğretmesi & 1 \\
\hline
\end{tabular}

İncelenen makalelerde tespit edilen öğretmen kaynaklı en büyük sorun alan bilgisine hâkim olamamadır. 20 araştırmada bu sorun yer almaktadır. Öğretmenlerin yanlış yöntem ve teknik kullanması (9), öğretmenlerin aldıkları eğitimlerin yetersiz olması (7), öğretmenlerin ayrı bir eğitim almaması (3), öz yeterlik eksikliği hissetmeleri (2), programlardan haberdar olmamaları (2), dil bilgisi odaklı eğitim yapmaları (1), tecrübe eksiklikleri (1) ve uzman olmayan kişilerin Türkçe öğretmesi (1) yaşanan öğretmen kaynaklı diğer sorunlardır.

Suriyelilere Türkçe öğretiminde yaşanan program temelli sorunlarla ilgili bulgular Tablo 5'te verilmiştir: 


\begin{tabular}{lc}
\hline & $f$ \\
\hline Müfredat eksikliği & 9 \\
Müfredatın hedef kitleye uygun olmaması & 6 \\
Eğitim süresinin yetersiz olması & 5 \\
\hline
\end{tabular}

İncelenen makalelerde tespit edilen program temelli en büyük sorun müfredat eksikliğidir (9). Çalışmalar incelendiğinde genellikle üniversitelere bağlı Türkçe/dil öğretim merkezinde görev yapan öğreticiler tarafından bu sorunun ortaya konulduğu görülmektedir. Milli Eğitim Bakanlığına bağlı okullarda ve halk eğitim merkezlerinde görev yapan öğretmenler ise genellikle Türkçe Öğretim Programı’nın veya MEB Hayat Boyu Öğrenme Genel Müdürlüğünün yayımladığı Yabancılara Türkçe Öğretimi Kurs Programı'nın hedef kitleye uygun olmadığını bildirdiği görülmektedir (6). Verilen eğitimlerin süresinin yetersiz olması (5) da çalışmalarda tespit edilen diğer sorundur.

Suriyelilere Türkçe öğretiminde yaşanan sınıf ortamından kaynaklanan sorunlarla ilgili bulgular Tablo 6' da verilmiştir:

Tablo 6. Suriyelilere Türkçe Öğretiminde Yaşanan Sınıf Ortamından Kaynaklanan Sorunlar

\begin{tabular}{lc}
\hline & $f$ \\
\hline Disiplin sorunları & 11 \\
Sinıfların dil öğretimi için elverişsiz olması & 7 \\
Dil seviyesi farklı öğrencilerin aynı sınıfta olması & 6 \\
Sinıf mevcudunun fazla olması & 6 \\
Devamsızlık & 5 \\
Ana dili kullanımı & 4 \\
Sınıfların teknolojik donanım eksikliği & 2 \\
\hline
\end{tabular}

Suriyelilere Türkçe öğretiminde yaşanan sınıf ortamından kaynaklanan sorunlara odaklanan 16 araştırma incelendiğinde; 11 araştırmada sınıflarda disiplin problemlerinin yaşandığı, 7 araştırmada sınıfların dil öğretimi için elverişli olmadığı, 6 araştırmada aynı sınıfta dil seviyesi farklı öğrencilerin olduğu, yine 6 araştırmada sınıf mevcutlarının fazla 
olduğu, 5 çalışmada öğrencilerin devamsızlık yaptıkları, 4 araştırmada derslerde ana dili kullanıldığg ve 2 araştırmada da sınıfların teknolojik donanım açısından yeterli olmadığı ile ilgili sorunların verildiği görülmektedir.

Suriyelilere Türkçe öğretiminde yaşanan öğrenme alanlarıyla ilgili sorunlara ilişskin bulgular Tablo 7'de verilmiştir:

Tablo 7. Suriyelilere Türkçe Öğretiminde Yaşanan Öğrenme Alanlarlyla İlgili Sorunlar

\section{$f$}

Telaffuz sorunları

14

Yazma becerisinde zorlanma

Okuduğunu anlamama

Dil bilgisi kaynaklı sorunlar

Yazım hataları yapma

Akıcı konuşamama

Kelime hazinesinin yetersizliği

Dinlediğini anlayamama

İlk okuma - yazma sorunları

Yöresel ağız özelliklerini kullanma

1

Suriyelilere Türkçe öğretiminde yaşanan sorunlarla ilgili hazırlanan makaleler incelendiğinde öğrenme alanlarıyla ilgili olarak; telaffuz sorunları (14), yazma becerisinde zorlanma (11), okuduğunu anlamama (10), dil bilgisi kaynaklı sorunlar (9), yazım hataları yapma (6), akıcı konuşamama (5), kelime hazinesinin yetersizliği (4), dinlediğini anlayamama (4), ilk okuma-yazmada yaşanan sorunlar (2) ve yöresel ağız özelliklerini kullanma (1) gibi sorunların verildiği görülmektedir.

Suriyelilere Türkçe öğretiminde yaşanan aile ve çevre kaynaklı sorunlara ilişkin bulgular Tablo 8'de verilmiştir: 


\begin{tabular}{lc}
\hline Çevrenin Arapça konuşması & $f$ \\
İlgisizlik & 6 \\
Kimlik kaybı korkusu & 2 \\
Türkçeye karşı olumsuz tutum & 2 \\
Çocuğu çalıştırma & 2 \\
Okul ile işbirliği yapmama & 1 \\
Sosyal medyada Türkçenin doğru kullanılmaması & 1 \\
\hline
\end{tabular}

Suriyelilere Türkçe öğretiminde yaşanan sınıf yönetiminden kaynaklanan sorunlara odaklanan 9 araştırma incelendiğinde; 6 araştırmada çevrede Arapça konuşulması, 2 araştırmada ailenin ilgisizliği, 2 araştırmada kimlik kaybı yaşanacağına dair hissedilen korku, yine iki çalışmada ailenin Türkçeye karşı olumsuz tutumu, 1 çalışmada ailenin çocuğu çalıştırması, 1 çalışmada ailenin okul ile işbirliği yapmaması ve yine bir çalışmada da sosyal medyada Türkçenin doğru kullanılmamasıyla ilgili sorunlara değinildiği görülmektedir.

\section{Sonuç ve Tartışma}

Suriyelilere Türkçe öğretiminde yaşanan sorunları, ilgili makaleler 1şığında meta analiz yöntemiyle ele almayı amaçlayan bu çalışmada ilgili makaleler örneklem, araştırma modeli/deseni, veri toplama araçları, veri analiz yöntemleri ve bulguları açısından değerlendirilmiştir. Araştırmanın bu bölümünde ise elde edilen bulguların, sonuçları verilmiş ve araştırma problemleri doğrultusunda tartışması yapılmıştır.

İncelenen makalelerin yazar sayısına bakıldığında daha çok iki yazarlı araştırmaların ön plana çıktığı, dört ve daha fazla yazarlı araştırmaların ise çok fazla tercih edilmediği görülmektedir. Araştırmaların yayın yılına bakıldığında da daha çok 2011 yılında başlayan iç savaş nedeniyle Suriyelilerin Türkiye’ye gelmesinden sonra yayımlandıkları, iç savaştan önce yayımlanan bir çalışmanın olduğu tespit edilmiştir. Yayımlanan çalışmaların yarıya yakını (\%34.3) 2018 yılında yayımlanmıştır. Araştırmaların büyük kısmının (\%76.5) yayın dili ise Türkçedir. 
İncelenen araştırmaların yöntem kısımlarına bakıldığında araştırma modeli/deseni olarak olgubilim (\%39.06) ve durum çalışması (\%23.4) desenlerinin kullanıldı̆̆ deneysel (\%4.6) modelin ise çok fazla tercih edilmediği tespit edilmiştir. Araştırmaların örneklemini ise daha çok eğiticiler (\%64.06) oluşturmaktadır. Bu duruma göre sorunların tespitinde, örneklem çeşitliliğinin çok olmadığını söylemek mümkün olabilecektir. Araştırmalarda veri toplama aracı olarak ise görüşme yöntemine (\%70.3) başvurulduğu göze çarpmaktadır. Bu sonuç veri toplama aracı açısından da çok çeşitlilik olmadığını göstermektedir. Veri analiz yöntemi olarak ise çalışmaların çoğunda içerik analizi (\%62.5) yönteminin kullanıldığı görülmektedir. Araştırmaların genel olarak yöntem bölümleri değerlendirildiğinde daha çok yöntem olarak birbirine benzeyen araştırmaların yapıldığı ve çok çeşitlilik arz etmediklerini söylemek mümkündür.

Suriyelilere Türkçe öğretiminde yaşanan sorunlara değinen araştırmaların bulgular kısmına bakıldığında ise genellikle Suriyelilere Türkçe öğretiminde yaşanan materyal sorunlarına, Türkçenin dil özelliklerinden kaynaklanan sorunlara, duyuşsal sorunlara, öğretici kaynaklı sorunlara, müfredat sorunlarına, öğretim ortamıyla ilgili sorunlara, öğrenme alanlarıyla ilgili sorunlara, aile ve çevre kaynaklı sorunlara değinildiği görülmektedir.

İncelenen araştırmalarda ele alınan sorunlardan biri materyal sorunlarıdır. Materyaller yabancılara Türkçe öğretiminde asli unsurlardan biridir ve onlardan kaynaklı sorunlar öğretim sürecini olumsuz etkilemektedir. Nitekim araştırmalarda da materyallerden kaynaklanan sorunlara değinilmektedir. Alanyazın incelendiğinde Suriyelilere Türkçe öğretiminde yaşanan materyal sorunuyla ilgili; materyal eksikliği (Cırıt Karaağaç ve Güvenç, 2019; Duruel, 2016; Gencer, 2017; Gün, 2015a; Phutkaradze ve İnce, 2018;); kitapların yetersiz olması, seviyeye uygun olmaması veya fiziksel yetersizliği (Biçer ve Kılıç, 2017; Dilek vd., 2018; Gün, 2015b; Gün ve Ağırman, 2018); materyallerin içeriksel ve fiziksel yetersizliği veya seviyeye uygun olmaması (Doğan ve Ateş, 2018), öğretmen kılavuz kitabının olmaması (Şen ve Solak, 2019) ve kitapların belli becerilere yönelik olması (Biçer ve Kılıç, 2017) gibi sorunların ele alındığı görülmektedir. Materyal sorunları sadece Türkçenin yabancı dil olarak öğretilmesinde karşımıza çıkan sorunlar değildir. Farklı dillerin öğretilmesinde de bu sorunları görmekteyiz. İngilizcenin mültecilere yabancı dil olarak öğretilmesinde de benzer sorunlar görülmektedir. Deem ve Marshall (1980) da yaptıkları araştırmada İngilizce öğretiminde kullanılan kitapların seviyeye veya öğrenci özelliklerine uygun olmadığında öğretimde sorunlar ortaya çıktığını belirtmişlerdir. 
İncelenen araştırmalarda ele alınan bir diğer sorun ise Türkçenin dil özelliklerinden ve öğrencilerin yanlış öğrenmelerinden dolayı yaşanan sorunlardır. Özellikle öğrencilerin farklı bir alfabe kullanması veya bazı seslerin dillerinde olmaması bu sorunların yaşanmasına neden olmaktadır. Bu konuyu ele alan araştırmalar incelendiğinde Türkçenin dil özelliklerinden kaynaklanan sorunlarla ilgili; alfabe farklılığı ve Türkçenin yapısal farklılıkları (Biçer, 2017; Demirci, 2015; Erdem, 2017; Erdem, Kaya ve Y1lmaz, 2017; Gözübüyük Tamer, 2020; Şengül, 2015; Taşkaya ve Ersoy, 2016); harflerin karıştırılması, ünlü harflerin yanlış kullanılması ve ünsüz harflerin yanlış kullanılması (Beyhan ve Epçaçan, 2018; Şengül, 2014); büyük harflerin yanlış kullanılması ve noktalama işaretlerinin kullanılmaması (Kara, 2010) ve çok fazla kural olması (Akkaya, 2013) gibi sorunların tespit edildiği görülmektedir. Hedef dilin sahip olduğu özellikler o dili öğrenen yabancı öğrenciler için bazı sorunların ortaya çıkmasına neden olabilmektedir. Nitekim bu durum sadece Türkçe için geçerli değildir. David West ve Karen (2010) de yaptıkları araştırmada Güney Koreli ve Kuzey Koreli öğrencilerin İngilizce öğrenirken dil özelliklerinden dolayı sorun yaşadıklarını tespit etmişlerdir. Benzer şekilde Deem ve Marshall (1980) de yine Çinhindi bölgesinden göçen mültecilerin İngilizce öğrenirken dil özelliklerinden kaynaklı sorunlar yaşadıklarını bildirmişlerdir. Karam, Kibler ve Yoder (2017) tarafından Suriyeli mülteciler üzerine yapılan çalışmanın sonuçları da bu bulguları destekler niteliktedir. İngilizce öğrenen Suriyeli mültecilerin de dil özelliklerinden kaynaklı sorunlar yaşadıkları bu çalışmada tespit edilen bulgulardandır.

Araştırmalarda karşımıza çıkan diğer bir sorun ise duyuşsal sorunlardır. Öğretim sürecinin olmazsa olmazı öğrencilerin duygusal açıdan hissettikleri, dil öğretim sürecini doğrudan etkilemektedir. Öğrencilerin hissettiği olumlu duygular süreci olumlu etkilerken olumsuz duygular ise sürece ket vurmaktadır. Araştırmalarda, Suriyelilere Türkçe öğretiminde karşılaşılan duyuşsal sorunlarla ilgili motivasyon eksikliği olması, Türkçeye karş1 olumsuz tutum sergileme, Türkçe öğrenmeye karşı direnç gösterme, psikolojik sorunlar yaşama, kaygı duyma, benliğini kaybetme korkusu yaşama, ön yargılı olma ve öz güven eksikliği hissetme (Aydın ve Kaya, 2019; Bozkırlı vd., 2018; Bulut vd., 2018; Erdem, 2016; Gürbüz ve Güleç, 2016; Moralı, 2018; Yıldı, 2016) gibi sorunların ele alındığı tespit edilmiştir. İngilizce ve Almanca öğretiminde de benzer sonuçlara rastlanmaktadır. Karam, Kibler ve Yoder (2017) araştırmalarında mültecileri öğrenicilerin özgüven eksikliği yaşadıklarını ve bunun da dil öğretimini olumsuz etkilediği; Koçak ve Çobanoğulları (2017) da öğrencilerin dile karşı tutumlarının Almanca öğretiminin başarısında etkili olduğu sonuçlarına ulaşmışlardır. 
Suriyelilere Türkçe öğretiminde yaşanan sorunlara değinen araştırmalarda ele alınan bir diğer sorun da öğreticilerden kaynaklanan sorunlardır. Öğretmen Yetiştirme ve Geliştirme Genel Müdürlüğü tarafından yayımlanan “Öğretmenlik Mesleği Genel Yeterlilikleri”ne; (MEB, 2017) göre eğitimin başlatıcısı, geliştiricisi ve uygulayıcısı olması nedeniyle öğretmenler, eğitim sisteminin en hayati ögesidir. Buna göre dil öğretiminde de vazgeçilmez bir unsur olarak kabul edilebilecek öğretmen veya öğretim elemanı, Türkçenin öğretilmesinde çok önemli bir yere sahiptir. Öğreticilerin öğrenme sürecinde olumlu veya olumsuz yaptıkları her şey süreci etkiler. Yapılan araştırmalarda elde edilen bulgular da bu doğrultudadır. Araştırmalara göre Suriyelilere Türkçe öğretiminde yaşanan öğretici kaynaklı sorunları; öğretmenlerin alan bilgisine hâkim olmaması, mevcut programlardan haberdar olmaması ve uzman olmayan kişilerin derse girmesi (Er ve Bayındır, 2015; Erdoğan ve Kana, 2019; Eyüp vd., 2017; Gencer, 2017; Kardeş ve Akman, 2018; Korkmaz, 2018; Pilancı vd., 2020; Şahin ve Sümer, 2018); öğretmenlerin yanlış yöntem-teknik kullanması, dil bilgisi odaklı eğitim yapması, tecrübe eksikliğinin olması ve öz yeterlik eksikliği hissetmesi (Gencer, 2017; Taşkaya ve Ersoy, 2016); öğretmenlerin aldıkları eğitimin yetersiz olması ve öğretmenlerin herhangi bir eğitim almaması (Boylu ve Işık, 2019; Özenç ve Saat, 2019; Özkale ve Yanpar Yelken, 2020; Uğurlu ve Kayhan, 2017; Yaşar ve Amaç, 2018) şeklinde sıralamak mümkündür. İngilizcenin yabancı dil olarak öğretiminde de benzer sorunlar karşımıza çıkmaktadır. Karam, Kibler ve Yoder (2017) de araştırmalarında yeterli eğitim almayan öğretmenlerin İngilizce öğretirken sorun yaşadıkları sonucuna ulaşmışlardır. Dil öğretiminde öğreticinin alan bilgisine hakimiyeti, tutumu, davranışları, kullandığı yöntem-teknik ve araçlar hedef dilin öğrenilmesinde oldukça önemlidir. Nitekim Baynham (2006) da yaptığı araştırmada öğretmenin yol gösterici olduğu durumlarda öğrencilerin dil öğrenirken daha rahat olduklarını ve dili daha kolay öğrendiklerini tespit etmiştir.

İncelenen araştırmalarda göze çarpan bir diğer sorun da program temelli sorunlardır. Araştırmalara göre sınıflarında Suriyeli öğrenci bulunan öğretmenler daha çok Türkçe öğretim programlarının bu öğrenciler için uygun olmadığı ile ilgili görüş bildirirken, Türkçe/dil öğretim merkezlerinde görev yapan öğretim elemanlarının ise müfredat eksikliğinden dolayı sorunlar yaşandığını, geçici eğitim merkezleri veya halk eğitim merkezlerinde görev yapan öğreticiler ise sürenin yetersiz olduğunu bildirmektedir. Suriyelilere Türkçe öğretiminde müfredat kaynaklı sorunlara değinen araştırmalara göre bu sorunlar; müfredatın olmaması, müfredatın hedef kitleye uygun olmaması ve eğitim sürelerinin yetersiz olması (Aykırı, 2017; İmamoğlu ve Çalışkan, 2017; Özer, Komşuoğlu ve Ateşok, 2016) şeklinde verilebilir. Karam, 
Kibler ve Yoder (2017) de İngilizce öğretiminde sistemli bir programın olmamasının dil öğretimini aksattığından bahsetmektedir.

Araştırmalarda ele alınan diğer sorun da öğretim ortamından kaynaklanan sorunlardır. $\mathrm{Bu}$ sorunların bir kısmı öğrenciden dolayı bir kısmı ise kurumlardan dolayı yaşanmaktadır. $\mathrm{Bu}$ sorunları iki şekilde ele almak mümkündür. Sınıf yönetimi ve öğrenme ortamı. Araştırmalarda sınıf yönetiminden kaynaklanan sorunlar; disiplin sorunlarının olması, farklı dil seviyesine sahip öğrencilerin aynı sınıfta olması, devamsızlık sorunlarının olması ve sınıflarda ana dili kullanımının olması (Balkar, Şahin ve Işıklı Babahan, 2016; Taşkaya ve Ersoy, 2016; Taşkın ve Erdemli, 2018) diye verilirken sınıf ortamından kaynaklanan sorunlar ise sınıf mevcudunun fazla olması, sınıfların fiziksel açıdan dil öğretimi için uygun olmaması ve sınıfların teknolojik açıdan yetersiz olması (Aykırı, 2017; Güven ve İşleyen, 2018; Koçoğlu ve Yanpar Yelken, 2018) şeklinde verilmektedir.

Suriyelilere Türkçe öğretiminde yaşanan sorunlara değinen araştırmalarda karşımıza çıkan diğer sorun da öğrenme alanlarında yaşanan problemlerdir. Yabancılara Türkçe öğretiminin temel amacı, öğrencilerin kendilerini yazılı ve sözlü olarak tam ve doğru ifade edebilmeleri ve karşılarındakini anlayabilmeleridir. Bu açıdan bakıldığında dil becerilerinde veya diğer öğrenme alanlarında yaşanan sorunlar, öğrencilerin kendilerini ifade etmelerinde problem yaşamalarına neden olacaktır. Araştırmalara göre öğrencilerin öğrenme alanlarında yaşadıkları sorunlar şöyle verilebilir: telaffuz sorunları yaşama, akıcı konuşamama, yöresel ağız özelliklerini kullanma, dinlediğini anlayamama (Akkaya ve Ulum, 2018; Aydın ve Kaya, 2019; Cirıt Karaağaç ve Güvenç, 2019; Dönmez ve Paksoy, 2015; Erdem, Şengül, Gün ve Büyükaslan, 2015; Yaşar ve Amaç, 2018); okuduğunu anlayamama, yazma becerisinde zorlanma, yazım hataları yapma, ilk okuma-yazmada sorun yaşama (Aykırı, 2017; Erdem, 2017; Kara, 2010; Kuzu Jafari, Tonğa ve Kışla, 2018; Solak ve Çelik, 2018; Taşkaya ve Ersoy, 2016; Taşkın ve Erdemli, 2018); dil bilgisi kaynaklı sorunlar ve kelime hazinesinin yetersiz olması (Demirci ve Dinçaslan, 2016; Demirgüneş, 2017; Gürbüz ve Güleç, 2016; Kan ve Utlu, 2017). Farklı dillerin öğretilmesinde de öğrenme alanlarıyla ilgili sorunlar mevcuttur. İngilizcenin yabancı dil olarak öğretilmesinde gramer sorunlarının yaşandığı veya konuşma becerisinde öğrencilerin zorlandığ sorunlardandır. Öğrenme alanlarında yaşanan sorunlar farklı yöntem ve teknikler kullanılarak giderilebilir. Örneğin Suriyeli öğrencilerin Türkçe öğrenirken yazma becerisinde yaşadığı bazı sorunların süreç temelli yazma yöntemleri kullanılarak giderilebildiği yapılan çalışmalarla ortaya konmuştur (Öztürk ve Alan, 2019, 2020) 
Suriyelilere Türkçe öğretiminde yaşanan sorunları inceleyen araştırmalarda karşımıza çıkan son sorun ise aile ve çevreden kaynaklanan sorunlardır. Yabancı bir dil öğrenirken her ne kadar öğretmen, öğrenci, materyal, öğrenme ortamı önemliyse aile ve çevre de en az o kadar önemlidir. Çünkü öğrencinin motivasyonundan hedef dili kullanma sıklığına kadar etkili olan faktördür aile ve çevre. Araştırmalarda da Türkçe öğrenen Suriyeli öğrencilerin yaşadıkları aile ve çevre kaynaklı sorunlara değinilmiştir. Bu sorunlar; çevrede Arapça konuşulması (Boylu ve Iş1k, 2020; Güngör ve Şenel, 2018; Şimşir ve Dilmaç, 2018); ilgisizlik, kimlik kaybı korkusu, ailenin Türkçeye karşı olumsuz tutumu, çocuğun çalıştırılması, ailenin okul ile işbirliği yapmaması (Tanrıkulu, 2017) ve sosyal medyada Türkçenin doğru kullanılmaması (Ünal vd., 2018) olarak belirlenmiştir.

İncelenen araştırmalardan elde edilen bulgular neticesinde Suriyelilere Türkçe öğretiminde yaşanan sorunlarla ilgili şu öneriler verilebilir:

- İncelenen araştırmaların çoğuna yakınının sorunları tespit etmeye yönelik olduğu görülmektedir. Sorunların çözümüne yönelik de araştırmalar yapılabilir.

- Araştırmalara göre Suriyelilere Türkçe öğretiminde materyaller konusunda sorunlar yaşanmaktadır. Hedef kitleye yönelik materyallerin hazırlanması ve mevcut materyallerin de eksikliklerinin giderilmesi gerekmektedir.

- Suriyelilere Türkçe öğreten öğretmenlerin/öğretim elemanlarının yaşadıkları sorunların temelinde genellikle yabancılara Türkçe öğretimi hususunda alan bilgisine hâkim olmama görülmektedir. Yaşanan diğer sorunların artarak devam etmemesi için bu sorunun giderilmesi ve eğiticilerin gerekli donanımı kazanması sağlanmalıdır.

- Türkçenin dil özelliklerinden dolayı sorunlar yaşandığı tespit edilmiştir. Türkçe öğretirken kullanılan strateji, yöntem ve teknikler değiştirilerek bu sorunlar giderilmelidir.

- Suriyelilere yönelik bir müfredatın olmadığı veya kullanılan programların yeterli olmadığ1 yönünde sorunların olduğundan hareketle, hedef kitlelere uygun programların geliştirilmesi gerekmektedir.

- Araştırmacıların, tespit edilen sorunların çözümüne yönelik deneysel araştırmalar yapmaları desteklenmelidir. 
138

Y. Alan/ Pamukkale Üniversitesi Eğitim Fakültesi Dergisi, 52, 119-146, 2021

Etik Kurul İzin Bilgisi: Bu araştırma Meta-Analiz çalışması olduğundan etik kurul izni alınmamıştır.

Yazar Çıkar Çatışması Bilgisi: Yazarın beyan edeceği bir çıkar çatışması yoktur.

Yazar Katkısı: Makalenin hazırlanması ve düzeltilmesine ilişkin katkı ilgili yazar tarafindan gerçekleştirilmiştir. 


\section{Kaynakça ${ }^{1}$}

Açık, F. (2008, Mart). Türkiye'de yabancılara Türkçe öğretilirken karşılaşılan sorunlar ve çözüm önerileri. Uluslararası Türkçe Eğitimi ve Öğretimi Sempozyumu, sunulmuş bildiri, Doğu Akdeniz Üniversitesi Eğitim Fakültesi Türkçe Eğitimi Bölümü.

*Akkaya, A. (2013). Suriyeli mültecilerin Türkçe algıları. EKEV Akademi Dergisi, 17(56), 179-190.

*Akkaya, A. ve Ulum, Ö. G. (2018). Yabancı dil olarak Türkçe öğrenen Suriyeli sığınmacıların dil öğrenmeye ilişkin inançları. International Journal of Languages' Education and Teaching, 6(4), 1-11.

Alyılmaz, C. (2010). Türkçe öğretiminin sorunları. Turkish Studies, 5(3), 728-749.

*Aydın, H. ve Kaya, Y. (2019). Education for Syrian Refugees: The New Global Issue Facing Teachers and Principals in Turkey. Educational Studies, 55(1), 46-71. doi:10.1080/00131946.2018.1561454

*Aykırı, K. (2017). Sınıf Öğretmenlerinin Sınıflarındaki Suriyeli Öğrencilerin Eğitim Durumlarına İlişkin Görüşleri. Turkish Journal of Primary Education, (2), 44-56.

*Balkar, B., Şahin, S. ve Işı1klı Babahan, N. (2016). Geçici eğitim merkezlerinde (GEM) görev yapan Suriyeli öğretmenlerin karşılaştıkları Sorunlar. Eğitimde Kuram ve Uygulama, 12(6), 1290-1310.

Baynham, M. (2006). Agency and contingency in the language learning of refugees and asylum seekers. Linguistics and Education, 17(1), 24-39. doi:10.1016/j.linged.2006.08.008

*Beyhan, D. ve Epçaçan, C. (2018). Suriyeli öğrencilerin Türk eğitim sistemine entegrasyonu projesi kapsamında geçici eğitim merkezlerinde görev yapan dil öğreticilerinin dil öğretirken karşılaştıkları sorunlar ve çözüm önerileri. Turkish Studies, 13(19), 285306. doi:10.7827/TurkishStudies. 14040

Biçer, N. (2012). Hunlardan günümüze yabancılara Türkçe öğretimi. Uluslararası Türkçe Edebiyat Kültür Eğitim Dergisi, 1(4), 107-133.

\footnotetext{
1 Araştırma kapsamında incelenen makaleler * ile işaretlenmiştir.
} 
*Biçer, N. (2017). The Views of Syrian Refugees Migrating to Turkey on the Turkish Language and Culture: Kilis Case. Journal of Education and Training Studies, 5(3), 97-109. doi:10.11114/jets.v5i3.2100

Biçer, N. ve Alan, Y. (2019). Türk soylulara Türkçe öğretimi ile ilgili çalışmalara genel bir bakış. Fırat Üniversitesi Sosyal Bilimler Dergisi, 29(1), 143-157.

*Biçer, N. ve Kılıç, B. S. (2017). Suriyeli Öğrencilere Türkçe Öğretmek İçin Kullanılan Ders Kitaplarının Öğretmen Görüşleri Doğrultusunda Değerlendirilmesi. Ana Dili Eğitimi Dergisi, 5(4), 649-663. doi:10.16916/aded.329809

*Boylu, E. ve Işık, P. (2019). Suriyeli Mülteci Çocuklara Yabancı Dil Olarak Türkçe Öğretenlerin Yaşadıkları Durumlara İlişkin Görüşleri. GEFAD / GUJGEF, 39(2), 895936. doi:10.17152/gefad.421069

*Boylu, E. ve Işık, P. (2020). Suriyeli mültecilerin yoğun olarak yaşadığg illerde Türkçe öğrenme süreçleri üzerine öğretmen görüşleri. Bolu Abant İzzet Baysal Üniversitesi Ĕ̆itim Fakültesi Dergisi, 20(2), 1113-1128.

*Bozkırlı, K. Ç., Er, O. ve Alyılmaz, S. (2018). Teacher opinions-based evaluation of problems in Turkish İnstruction to Syrians. European Journal of Foreign Language Teaching, 3(2), 130-147. doi:10.5281/ZENODO.1251566

*Bulut, S., Kanat Soysal, Ö. ve Gülçiçek, D. (2018). Suriyeli öğrencilerin Türkçe öğretmeni olmak: Suriyeli öğrencilerin eğitiminde karşılaşılan sorunlar. Uluslararası Türkçe Edebiyat Kültür Eğitim Dergisi, 7(2), 1210-1238.

Burak, D. ve Amaç, Z. (2020). Mültecilerin ilkokuldaki eğitimi ve sınıf öğretmenleri için etkinlik örnekleri. M. A. Karaman, Z. Amaç, Y. Doğan ve F. Bektaş (Ed.), Panik Yok!!! Ben Mülteciyim içinde (2. bs.). Ankara: Vizetek Yayıncılık.

Candaş Karababa, Z. C. (2009). Yabancı dil olarak Türkçenin öğretimi ve karşılaşılan sorunlar. Ankara Üniversitesi Eğitim Bilimleri Fakültesi Dergisi, 42(2), 265-277.

*Cırıt Karaağaç, F. ve Güvenç, H. (2019). Resmi ilkokullara devam eden Suriyeli mülteci öğrencilerin eğitim sorunları. OPUS Uluslararası Toplum Araştırmaları Dergisi, 11(18), 530-568. doi:10.26466/opus.530733

Çalık, M. ve Sözbilir, M. (2014). İçerik analizinin parametreleri. Eğitim ve Bilim, 39(174), 33-38. 
David-West, A. \& Karen, C. (2010). Teaching English to North Korean refugees in South Korea: an interview with Karen Choi. North Korean Review, 6(1), 108-119. doi:10.3172/NKR.6.1.108

Deem, M. J. \& Marshall, W. J. (1980). Teaching a second language to Indochinese refugees when no program exists. International Literacy Association, 23(7), 601-605.

*Demirci, M. (2015). B1 seviyesinde Türkçe öğrenen Suriyeli öğrencilerin sesli okuma becerisiyle ilgili tespitler. Turkish Studies, 10(7), 333-358. doi:10.7827/TurkishStudies.8149

*Demirci, M. ve Dinçaslan, M. F. (2016). The use of valence of Syrian students learning Turkish as a foreign language. Eğitimde Kuram ve Uygulama, 12(5), 1011-1040.

Demirel, Ö. ve Şahinel, M. (2006). Türkçe ve sınıf ögretmenleri için Türkçe öğretimi (7. bs.). Ankara: Pegem Akademi.

*Demirgüneş, S. (2017). Microstructural (cohesion and coherence) text generation problems of Syrian refugee students learning Turkish. Universal Journal of Educational Research, 5(4), 581-590. doi:10.13189/ujer.2017.050407

*Dilek, Ş., Boyaci, B. ve Yaşar, E. (2018). Teaching Turkish as a second language to Syrian refugees. Educational Research and Reviews, 13(18), 645-653. doi:10.5897/ERR2018.3565

*Doğan, B. ve Ateş, A. (2018). Evaluation of Turkish language teaching for Syrian students who are learned in monetary schools by teachers (Malatya sample). Çocuk, Edebiyat ve Dil Ë̆itimi Dergisi, 1(1), 105-124.

*Dönmez, M. İ. ve Paksoy, S. (2015). Türkiye'de öğrenim gören Suriyeli öğrencilerin Türkçe öğrenmede karşılaştıkları sorunlar üzerine bir araştırma: Kilis 7 Aralık Üniversitesi örneği. International Journal of Languages' Education, 1907-1919. doi:10.18298/ijlet.366

Durmuş, M. (2013). Türkçenin yabancılara öğretimi: Sorunlar, çözüm önerileri ve yabancılara Türkçe öğretiminin geleceğiyle ilgili görüşler. Adlyaman Üniversitesi Sosyal Bilimler Enstitüsü Dergisi Türkçenin Ĕ̆itimi Öğretimi Özel Sayısı, 6(11), 207-228.

*Duruel, M. (2016). Suriyeli sığınmacıların eğitim sorunu. Atatürk Üniversitesi İktisadi ve İdari Bilimler Dergisi, 30(5), 1399-1414. 
*Er, A. R. ve Bayındır, N. (2015). Pedagogical approaches of elementary teachers for prımary refugee children. International Journal of Social and Educational Sciences, 2(4), 175185.

Er, O., Biçer, N. ve Bozkırlı, K. Ç. (2012). Yabancılara Türkçe öğretiminde karşılaşılan sorunların ilgili alan yazını ışı̆̆ında değerlendirilmesi. Uluslararası Türkçe Edebiyat Kültür Ĕ̆itim Dergisi Sayl, 1(2), 51-69.

*Erdem, C. (2017). Sınıfında mülteci öğrenci bulunan sınıf öğretmenlerinin yaşadıkları öğretimsel sorunlar ve çözüme dair önerileri. Medeniyet Eğitim Araştırmaları Dergisi, $1(1), 26-42$.

*Erdem, M. D. (2016). Instructors' opinions about the education on Turkish speaking abilities of Syrian students. the anthropologist, 24(2), 541-550. doi:10.1080/09720073.2016.11892048

*Erdem, M. D., Kaya, İ. ve Y1lmaz, A. (2017). Örgün eğitim kapsamındaki Suriyeli çocukların eğitimleri ve okul yaşantıları hakkında öğretmen görüşlerinin değerlendirilmesi. International Journal of Languages ' Education and Teaching, 5(3), 463-476

*Erdem, M. D., Şengül, M., Gün, M. ve Büyükaslan, A. (2015). Tekerleme alıştırmalarına dayalı etkinliklerin Türkçeyi yabancı dil olarak öğrenen Suriyeli Arapların konuşma becerilerine etkisi. Route Educational and Social Science Journal, 2(2), 1-11. doi:10.17121/ressjournal.322

*Erdoğan, D. ve Kana, F. (2019). Yaygın eğitim kurumlarında yabancılara Türkçe öğreten öğretmenlerin "Yabancı Diller Türkçe A1 Seviyesi Kurs Programını" uygulama süreci. International Journal of Languages' Education and Teaching, 7(4), 49-74.

*Eyüp, B., Aslan, N. ve Cevher, T. Y. (2017). Mültecilere Türkçenin yabancı dil olarak öğretilmesine yönelik uyum kursuna katılan öğreticilerin kurs hakkındaki görüşleri ve hazır bulunuşluk durumları. International Journal of Languages' Education, 5(4), 174-200. doi:10.18298/ijlet.2423

*Gencer, T. E. (2017). Göç ve eğitim ilişkisi üzerine bir değerlendirme: Suriyeli çocukların eğitim gereksinimi ve okullaşma süreçlerinde karşılaştıkları güçlükler. Journal of International Social Research, 10(54), 838-851. doi:10.17719/jisr.20175434652 
*Gözübüyük Tamer, M. (2020). Mülteci ve sığınmacı yetişkinlere sunulan Türkçe dil öğretiminin halk eğitim merkezi öğretmenleri tarafından değerlendirilmesi (Trabzon örneği). Karadeniz Araştırmaları, 17(65), 97-115.

*Gün, M. (2015a). The opinions of the instructors about the listening skills of Syrian students learning Turkish. International Journal of Social Sciences and Education, 1(4), 559569.

* Gün, M. (2015b). Yabancılara Türkçe öğretimi veren elemanların Adıyaman ili çadır kent bölgesinde Türkçe öğrenen Suriyeli Araplara Türk kültürü aktarımına ilişkin görüşleri. Cappadocia Journal of History and Social Sciences, 1(5), 119-138. doi:10.18299/cahij.61

*Gün, M. ve Ağırman, F. (2018). Öğretim elemanlarının Türkçe öğrenen Suriyeli Arap öğrencilere dil bilgisi öğretimine yönelik görüşleri. Çukurova Araştırmaları Dergisi, 4(2), 101-116. doi:10.18560/cukurova.1106

*Güngör, F. ve Şenel, E. A. (2018). Yabancı uyruklu ilkokul öğrencilerinin eğitim öğretiminde yaşanan sorunlara ilişkin öğretmen ve öğrenci görüşleri. Journal of Educational Sciences International, 8(2), 124-173.

*Gürbüz, R. ve Güleç, İ. (2016). Türkiye'de eğitim gören yabanc1 öğrencilerin Türkçeye ilişkin görüşleri: Sakarya Üniversitesi örneği. Sakarya University Journal of Education, 6(2), 141-153. doi:10.19126/suje.18712

*Güven, S. ve İşleyen, H. (2018). Sınıf yönetiminde iletişim, iletişim engelleri ve Suriyeli öğrenciler. International Journal of Social Humanities Sciences Research (JSHSR), 5(23), 1293-1308. doi:10.26450/jshsr.485

*İmamoğlu, H. V. ve Çalışkan, E. (2017). Yabancı uyruklu öğrencilerin devlet okullarında ilkokul eğitimine dair öğretmen görüşleri: Sinop ili örneği. Karabük Üniversitesi Sosyal Bilimler Enstitüsü Dergisi, 7(2), 529-546. doi:10.14230/joiss454

*Kan, M. O. ve Utlu, G. (2017). Errors in case markers made by Syrian students who learn Turkish in temporary education center. Journal of Education and Training Studies, 5(9), 205-212. doi:10.11114/jets.v5i9.2562

*Kara, M. (2010). Gazi Üniversitesi TÖMER öğrencilerinin Türkçe öğrenirken karşılaştıkları sorunlar ve bunların çözümüne yönelik öneriler. Türk Eğitim Bilimleri Dergisi, 8(3), 661-696. 
Karam, F. J., Kibler, A. K. \& Yoder, P. J. (2017). "Because even us, Arabs, now speak English": Syrian refugee teachers' investment in English as a foreign language. International Journal of Intercultural Relations, 60, 169-182. doi:10.1016/j.ijintrel.2017.04.006

*Kardeş, S. ve Akman, B. (2018). Suriyeli mültecilerin eğitimine yönelik öğretmen görüşleri. İlköğretim Online, 17(3), 1224-1237. doi:10.17051/ilkonline.2018.466333

Koçak, M. ve Çobanoğulları, F. (2017). Dünyada ikinci yabancı dil olarakAlmanca öğretiminde Danimarka örneği. Uluslararası Eğitim Bilimleri Dergisi, 1(1), 1-12.

*Koçoğlu, A. ve Yanpar Yelken, T. (2018). Suriyeli öğrencilere Türkçe dil becerileri kazandırma sürecinde ilkokul Türkçe dersi öğretim programları ile ilgili öğretmen görüşleri. Journal of Qualitative Research in Education, 6(2), 131-160. doi:10.14689/issn.2148-2624.1.6c2s $7 \mathrm{~m}$

*Korkmaz, E. (2018). Yabancılara Türkçe öğretiminde yaşanan bazı sorunlar ve çözüm önerileri. KSÜ Sosyal Bilimler Dergisi, 15(1), 89-104.

*Kuzu Jafari, K., Tonğa, N. ve Kışla, H. (2018). Suriyeli öğrencilerin bulunduğu sınıflarda görev yapan sınıf öğretmenlerinin görüşleri ve uygulamaları. Academy Journal of Educational Sciences, 2(2), 134-146. doi:10.31805/acjes.479232

Miles, M. B. ve Huberman, M. A. (1994). Qualitative data analysis. London: Sage Publication.

*Moralı, G. (2018). Suriyeli mülteci çocuklara Türkçenin yabancı dil olarak öğretiminde karşılaşılan sorunlar. OPUS Uluslararası Toplum Araştırmaları Dergisi, 8(15), 14261449. doi:10.26466/opus. 443945

Okur, A. (2013). Yabancılara Türkçe öğretiminde karşılaşılan sorunlara yönelik inceleme. The Journal of Academic Social Science Studies, 6(6), 877-892. doi:10.9761/JASSS1648

MEB (2017). Öğretmenlik mesleği genel yeterlilikleri. Öğretmen Yetiştirme ve Geliştirme Genel Müdürlüğü: Ankara.

*Özenç, E. G. ve Saat, F. (2019). Sınıf Öğretmenlerinin Suriyeli öğrencilerin eğitiminde karşılaştığ1 sorunlar. International Journal of Active Learning, 4(2), 60-74. 
*Özer, Y. Y., Komşuoğlu, A. ve Ateşok, Z. Ö. (2016). Türkiye'deki Suriyeli çocukların eğitimi: sorunlar ve çözüm önerileri. Akademik Sosyal Araştırmalar Dergisi, 4(37), 76-110.

*Özkale, U. ve Yanpar Yelken, T. (2020). Analysis of problems encountered by instructors teaching Turkish as a foreign language to Syrian children and their opinions on their participation in the certification program for teaching Turkish as a foreign language. Journal of Language and Linguistic Studies, 16(1), 185-212.

*Öztürk, J. ve Alan, Y. (2019). 4+1 Planlı yazma ve değerlendirme modelinin Türkçeyi yabancı dil olarak öğrenen öğrencilerin yazma becerilerine etkisi. Mustafa Kemal Üniversitesi Sosyal Bilimler Enstitüsü Dergisi, 16(44), 221-250.

*Öztürk, J. ve Alan, Y. (2020). Yabancı öğrencilerin bağdaşıklık araçlarını kullanma düzeylerinde $4+1$ planlı yazma ve değerlendirme modelinin etkisi. Uluslararası Türkçe Edebiyat Kültür Ĕ̌gitim Dergisi, 9(1), 293-315.

*Phutkaradze, M. ve İnce, B. (2018). Yabancı dil olarak Türkçe öğretiminde yeni bir hedef kitle: düzensiz göçmenler. Turkophone, 5(1), 24-40.

*Pilancı, H., Çalışır Zenci, S., Saltık, O. ve Yaşar, S. (2020). HEM'lerde Suriyeliler'e Türkçe öğreten öğretmenler üzerine bir araştırma. Dil Eğitimi ve Araştırmaları Dergisi, 6(1), 127-144. doi:10.31464/jlere.672475

*Solak, E. ve Çelik, S. (2018). Türkiye'de eğitim gören mülteci öğrencilerin dilsel sorunlarının incelenmesi. Uluslararası Sosyal Araştırmalar Dergisi, 11(57), 425-432. doi:10.17719/jisr.2018.2461

*Şahin, S. ve Sümer, S. (2018). The problems experienced in the integration process of Syrian students into the Turkish education system. Universal Journal of Educational Research, 6(5), 909-918. doi:10.13189/ujer.2018.060512

*Şen, F. ve Solak, E. (2019). Öğretici görüşlerine göre sığınmacı öğrencilere Türkçe öğretiminde karşılaşılan sorunların değerlendirilmesi: Kayseri ili örneği. International Journal of Language Academy, 7(4), 349-360. doi:10.29228/ijla.25856

*Şengül, K. (2014). Türkçenin yabancı dil olarak öğretiminde alfabe sorunu. Uluslararası Türkçe Edebiyat Kültür Eğitim Dergisi, 3(1), 325-339. 
*SSengül, M. (2015). The opinions of instructors teaching Turkish to foreigners about the writing skills of Syrian students. Journal of Education and Training Studies, 3(5), 177 186.

*Şimşir, Z. ve Dilmaç, B. (2018). Yabancı uyruklu öğrencilerin eğitim gördüğü okullarda öğretmenlerin karşılaştığı sorunlar ve çözüm önerileri. İlköğretim Online, 17(3), 17191737. doi:10.17051/ilkonline.2018.466425

*Tanrıkulu, F. (2017). Türkiye'de yaşayan Suriyeli çocukların eğitim sorunu ve çözüm önerileri. Liberal Düşünce Dergisi, 22(86), 127-144.

*Taşkaya, M. ve Ersoy, G. (2016). Suriyeli sığınmacılara Türkçe öğretiminde sınıf öğretmenlerinin uygulamaları. Çukurova Araştırmaları Dergisi, 2(1), 130-138. doi:10.18560/cukurova.31

*Taşkın, P. ve Erdemli, Ö. (2018). Education for Syrian refugees: problems faced by teachers in Turkey. Eurasian Journal of Educational Research, (75), 155-178.

*Tunga, Y., Engin, G. ve Çağıltay, K. (2020). Türkiye'deki Suriyeli çocukların eğitiminde karşılaşılan sorunlar üzerine bir alanyazın taraması. Inönü Üniversitesi Eğitim Fakültesi Dergisi, 21(1), 317-333. doi:10.17679/inuefd.535845

Türkben, T. (2018). Yabancı dil olarak Türkçe öğretimi alanında yapılan lisansüstü çalışmaların değerlendirilmesi. Uluslararası Türkçe Edebiyat Kültür Eğitim Dergisi, 7(4), 2464-2479.

*Uğurlu, N. I. ve Kayhan, N. (2017). Teacher opinions on the problems faced in reading and writing by Syrian migrant children in their first class at primary school. Journal of Education and Learning, 7(2), 76. doi:10.5539/jel.v7n2p76

*Ünal, K., Taşkaya, S. M. ve Ersoy, G. (2018). Suriyeli göçmenlerin yabancı dil olarak Türkçe öğrenirken karşılaştıkları sorunlar ve çözüm önerileri. Ahi Evran Üniversitesi Sosyal Bilimler Enstitüsü Dergisi, 4(2), 134-149.

*Yaşar, M. R. ve Amaç, Z. (2018). Teaching Syrian students in Turkish schools: experiences of teachers. Sustainable Multilingualism, 13(1), 225-238. doi:10.2478/sm-2018-0019

*Yıldız, N. (2016). Yabancılara Türkçe öğretiminde okuma öğretimi yöntemlerinin okuduğunu anlamaya etkisi. Recep Tayyip Erdoğan Üniversitesi Sosyal Bilimler Dergisi, 2(3), 98-112. 
The Problems Encountered When Teaching Turkish to Syrian People Based on the

\title{
Related Studies
}

Yakup Alan*

• Received: 04.06.2020 • Accepted: 03.11.2020 • Online First: 04.11.2020

\begin{abstract}
This study aims to examine the problems encountered when teaching Turkish language to Syrian people based on the related articles. In this regard, as a result of the literature review, 64 articles dealing with the problems in teaching Turkish to the Syrian were included in this study to be examined. In the study using meta-synthesis method, content analysis method was used to analyze the data. The general tendencies of the examined articles and the problems dealt with in the articles were classified and presented as graphs/tables. As a result of the conducted analysis, it was detected that the most of the articles had been designed with phenomenology, the teachers had been preferred as sample in general, the interview method had been employed as a data collection tool in the articles and the content analysis had been preferred as analysis method. Furthermore, it was observed that the articles had addressed wide variety problems.
\end{abstract}

Keywords: Turkish education, teaching Turkish to Syrian people, problems in teaching Turkish to the Syrian, literature review.

\section{Cited:}

Alan, Y. (2020). The Problems encountered when teaching turkish to syrian people based on the related studies. Pamukkale University Journal of Education, 52, 119-146.doi: 10.9779/pauefd.748162.

\footnotetext{
* Asst.Prof., Kilis 7 Aralık University, alanyakup@gmail.com, https://orcid.org/0000-0002-9888-1357
} 


\section{Introduction}

Although the beginning of teaching Turkish as a foreign language was initiated with Divanü Lügati't-Türk in many studies, according to Biçer (2012), there are evidences that Turkish was taught as a foreign language in Huns. This information is actually an indication of the deeprooted history of activities related to teaching Turkish as a foreign language. This process, which started during the Huns period, has progressed with each passing year and has reached the present century. In the process, the number of institutions and people dealing with the activities of teaching Turkish as a foreign language has increased significantly and units undertaking this mission have been opened both abroad and in the country. Today, activities related to teaching Turkish as a foreign language are carried out by Turkish / language teaching centers, public education centers, temporary education centers or private education institutions established within almost all universities in the country.

In recent years, the migration of millions of Syrians to our country due to the internal turmoil in Syria has caused a very rapid increase in Turkish teaching activities for them. Many institutions and organizations have started to carry out a series of activities in order to teach Turkish to Syrians so that they can be included in their integration and education processes. Turkish / language teaching centers affiliated to universities, the Ministry of National Education, Presidency for Turks Abroad and Related Communities, international / national organizations and foundations, public education centers and private education institutions are some of the institutions and organizations operating in this field. It is known that various problems have been seen in Turkish teaching activities carried out both abroad and domestically. Some of these problems are; problems arising from Turkish education programs, lack of materials, problems in teaching methods to foreigners, alphabet differences, problems arising from structural differences of Turkish and educators (Aç1k, 2008; Alyılmaz, 2010; Candaş Karababa, 2009; Demirel \& Şahinel, 2006; Durmuş, 2013; Er, Biçer and Bozkırlı, 2012; Okur, 2013).

With the start of teaching Turkish to Syrians, different problems have started to arise in addition to the problems already encountered in teaching Turkish to foreigners. The large number of students is one of the main factors that cause these problems to be seen. In addition, the opening of temporary education centers for Syrian students or the starting of these students to receive education in schools affiliated to the Ministry has added a different dimension to the problems experienced in Turkish teaching. Burak and Amaç (2020), in their study in which they reveal the situation of Syrian students receiving primary school education, mention that 
many problems arise from the lack of equipment of teachers, the inadequacy of the education programs and the education system. These problems cause teachers to be negatively affected while teaching Turkish. For these reasons, it is very important to identify the problems encountered in teaching Turkish to Syrians in order to eliminate these problems and to carry out more qualified Turkish teaching activities.

There are studies in the literature to determine the trends of the studies about the problems encountered in teaching Turkish as a foreign language (Biçer \& Alan, 2019; Er et al., 2012). There is also a literature review that examines the education problems of Syrians (Tunga, Engin, \& Çağıltay, 2020). The number of studies addressing the problems experienced in teaching Turkish to Syrians is quite high. When the literature is analyzed, the general problems seen in these studies are ; material problems (Beyhan \& Epçaçan, 2018; Boylu and Işık, 2019; Bulut, Kanat Soysal \& Gülçiçek, 2018; Doğan \& Ateş, 2018; Gözübüyük Tamer, 2020); problems encountered due to the language characteristics of Turkish (Demirci, 2015; Gün \& Ağırman, 2018; Koçoğlu \& Yanpar Yelken, 2018; Moral1, 2018; Şengül, 2014); affective problems (Bozkırlı, Er \& Alyılmaz, 2018; Dilek, Boyaci, \& Yaşar, 2018; Erdem, 2016; Yıldız, 2016); problems arising from trainers (Erdoğan \& Kana, 2019; Eyüp, Aslan \& Cevher, 2017; Özkale \& Yanpar Yelken, 2020; Pilancı, Çalışır Black, Saltık \& Yaşar, 2020); curriculum-related problems (Aykırı, 2017; Şen \& Solak, 2019; Ünal, Taşkaya, \& Ersoy, 2018); classroom management and the teaching environment problems (Balkar, Şahin, \& Işıklı Babahan, 2016; Kardeş \& Akman, 2018); problems experienced in learning areas (Demirgüneş, 2017; Kan \& Utlu, 2017; Kara, 2010); problems related to family and environment (Güngör \& Şenel, 2018). It is very important to identify these problems encountered in teaching Turkish to Syrians and to offer solutions to them. Because, in order to teach Turkish more systematically and functionally, the problems experienced should be minimized. For this reason, the value of researches that both identify the problems and contain the results of studies aimed at solving these problems is an indisputable fact. Although there are many studies aimed at identifying the problems experienced in teaching Turkish to Syrians or finding solutions, there is no research that determines the general tendencies of these studies. It is thought that the research will contribute to the literature in terms of revealing the general tendencies of the studies addressing the problems experienced in teaching Turkish to Syrians and providing an overview of the identified problems. 


\section{Purpose}

The aim of this research is to deal with the problems encountered in teaching Turkish to Syrians in line with related studies. In this context, the following questions were sought in the study:

1. What is the distribution of research models / patterns used in the researches analyzed?

2. What is the sample group distribution in the studies analyzed?

3. What are the data collection tools used in the studies analyzed?

4. What are the data analysis methods used in the researches analyzed?

5. Which problems in teaching Turkish to Syrians are addressed in the anlyzed studies?

\section{Method}

In this part of the research; information was given about the research model, study group, data collection and data analysis method.

\section{Research Pattern}

The meta-synthesis model was used in this study, which aims to evaluate the general tendencies of the articles prepared to deal with the problems encountered in teaching Turkish to Syrians and the problems addressed in the articles. According to Çalık \& Sözbilir (2014), common and different aspects of researches prepared in a particular field in meta-synthesis research are discussed and a reference source is created. In this research, this method was used to reflect the problems experienced in teaching Turkish to Syrians.

\section{Data Collection and Inclusion Criteria for Research}

In the research, in order to determine the studies dealing with the problems of teaching Turkish to Syrians, Google Scholar search engine, Yandex search engine, Ulakbim and Sobiad databases were searched. The surveys were carried out with key expressions such as "Teaching Turkish to Syrians, problems in teaching Turkish to Syrians, problems in teaching Turkish to foreigners, educational problems of refugees". The scans were made in both Turkish and English. As a result of the scans, many studies were reached, and those not related to the problems were eliminated and 90 studies remained. In these studies, the criteria to be published between 2010 and 2020, to be an article and to address the problems experienced in Turkish teaching to Syrians were sought. Twenty-six studies that did not have the nature of an article, did not state that the study was aimed at teaching Turkish to Syrians, touched on 
the problems experienced in teaching Turkish to Arabs, but still did not have information about Syrians were eliminated, and 64 articles were included in the study. The information about the number of authors, publishing years and publication languages of the studies included in the study are given in Chart 1, Chart 2 and Chart 3:

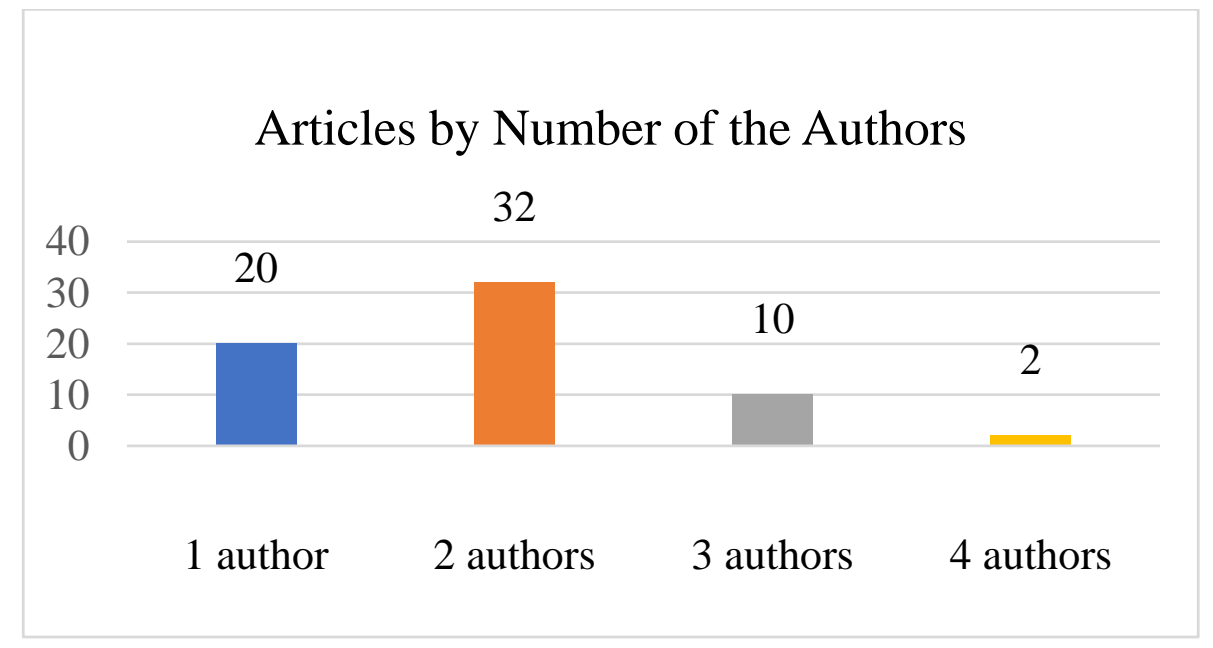

Chart 1: Number of Authors of Articles

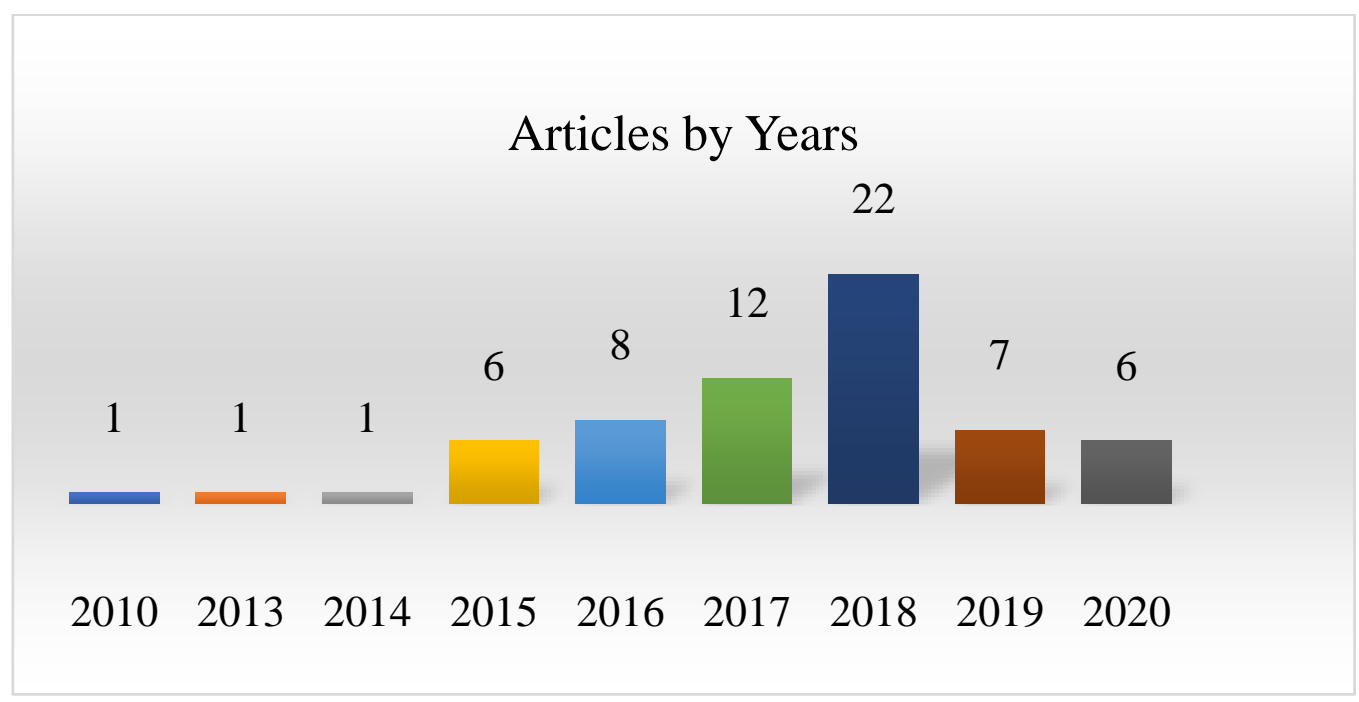

Chart 2: Distribution of Articles by Years 


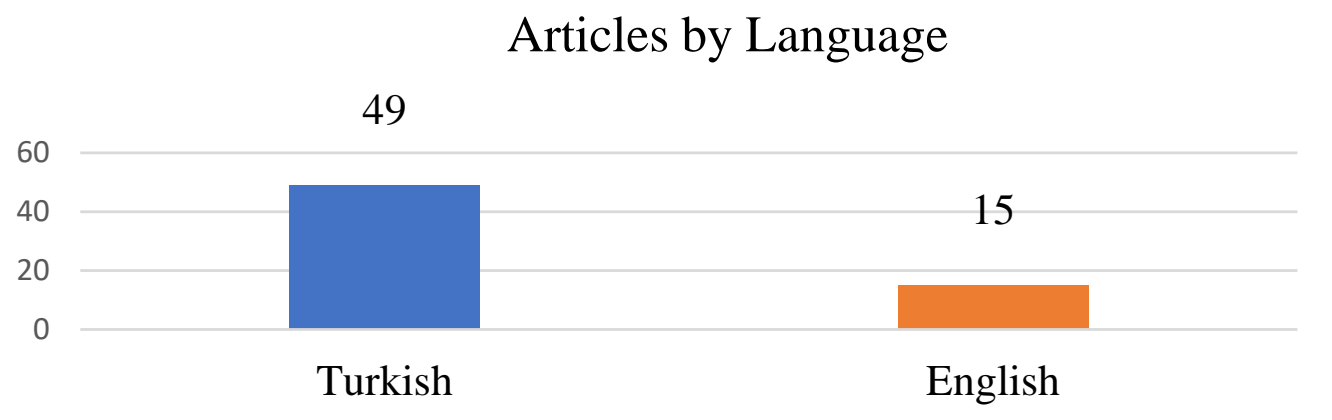

Chart 3: Distribution of Articles by Language

\section{Data Analysis}

Content analysis method was used in the analysis of the articles dealing with the problems experienced in teaching Turkish to Syrians. In the content analysis, the general tendencies of the analyzed articles (research model / pattern, sample group, publication year, number of authors, publication languages, data collection tools and data analysis methods) were primarily determined. Later, the problems discussed in the articles were classified and presented in tables. Another expert, except from the researcher, analyzed 8 randomly selected articles from the sample. In order to determine the reliability of the data, the agreement between the analyzers was determined. As a result of the calculations made using the formula of Miles and Huberman (1994), it was found that the agreement between the analysts was .86. The data in the research were presented by using graphics-charts, tables and frequencies.

\section{Results}

\section{Results Related to the Methods of the Articles Examined}

In this part of the research, information about the research model / pattern, sampling, data collection tools and data analysis methods, which constitute the method part of the articles examined, was presented.

Information about the research models / patterns of the articles analyzed was presented in Chart 4: 


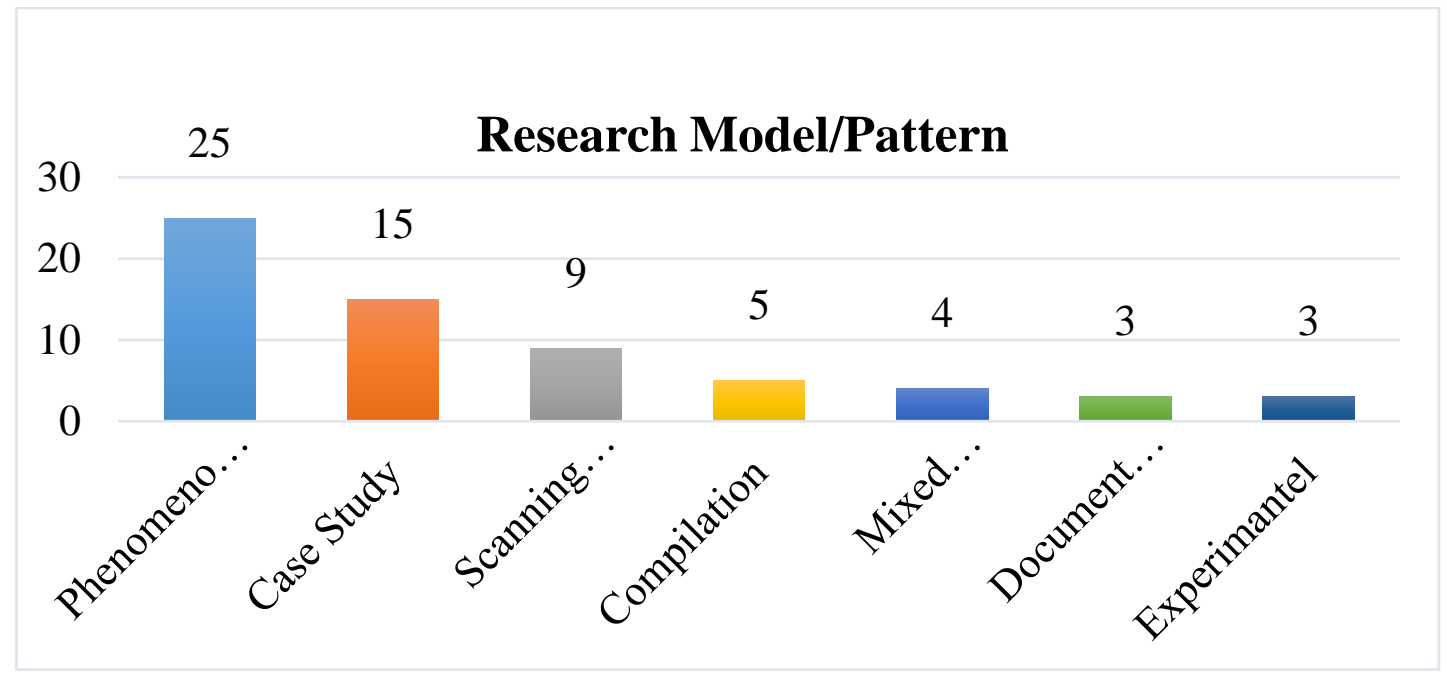

\section{Chart 4. Distribution of Articles According to Research Models/Patterns}

According to Chart 4; Phenomenology is the most commonly used model / pattern to identify the problems experienced in teaching Turkish to Syrians.

Information about the samples of the articles analyzed was presented in Chart 5:

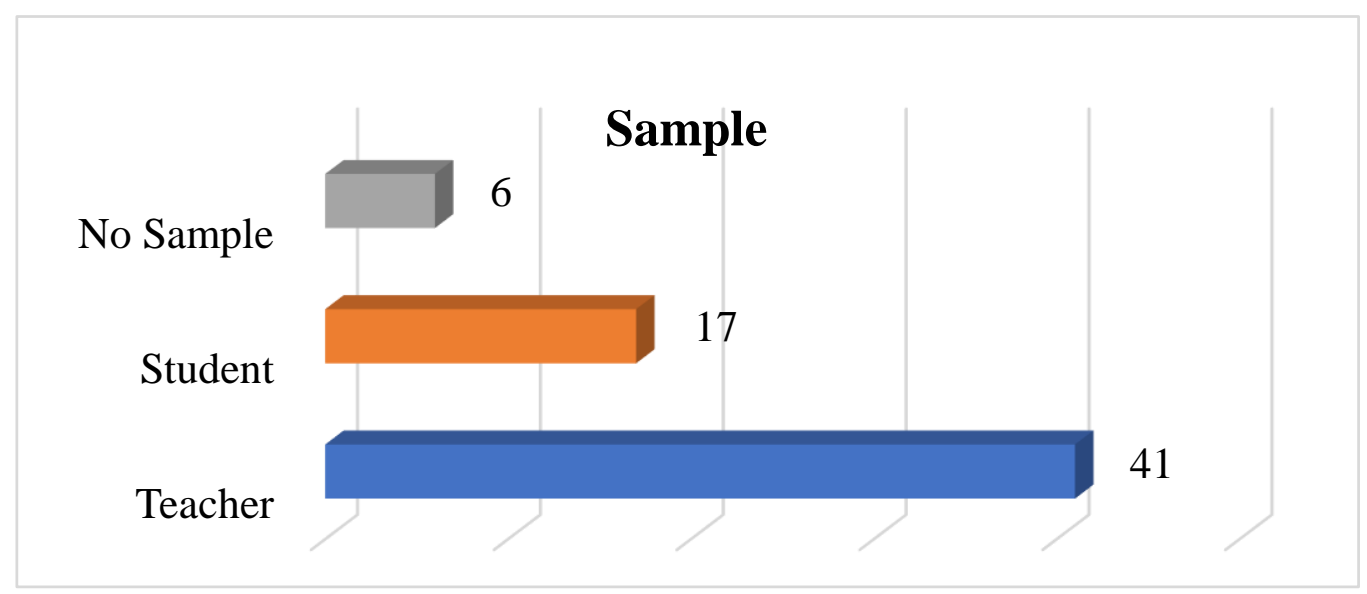

Chart 5: Distribution of Articles According to Their Samples

When Chart 5 is analyzed, it is seen that the sample of the most of the studies (41) prepared on the problems experienced in teaching Turkish to Syrians consist of teachers. When the studies are examined, it is seen that the opinions of primary, secondary and high school teachers, teachers working within the scope of the PIKTES project, lecturers working in Turkish / language teaching centers or teachers in public education centers were taken. In 17 studies, it was foumd out that students' opinions were obtained about the problems experienced. In addition, no sample was used in 6 studies.

Information about the data collection tools of the articles examined is given in Chart 6: 


\section{Data Collection Tool}

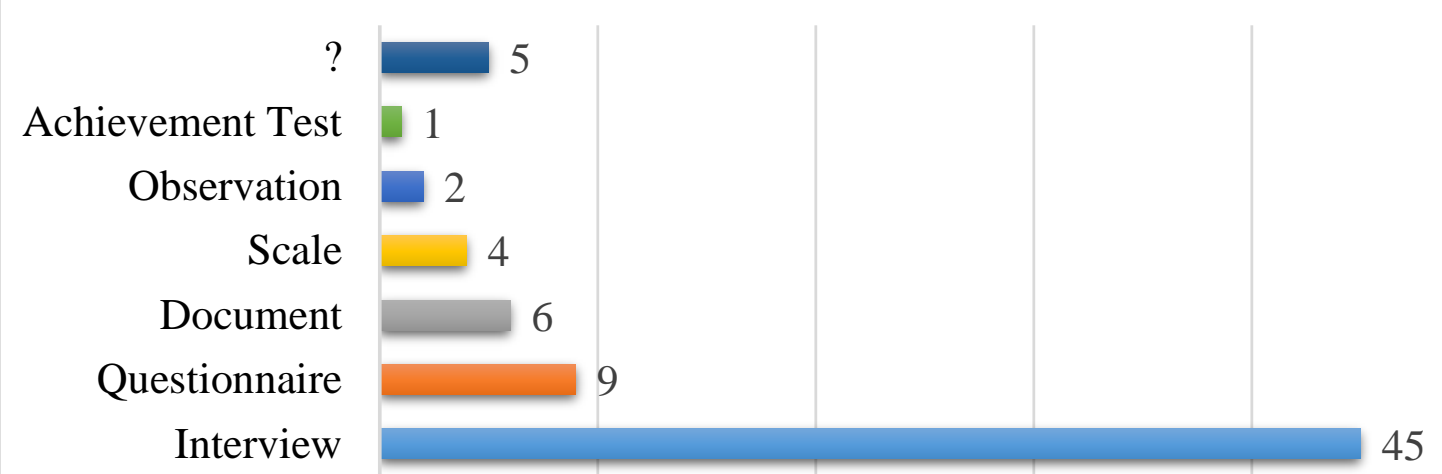

\section{Chart 6: Distribution of Articles' Data Collection Tools}

When the data collection tools of the articles analyzed are analyzed, it is seen that the data in most of the studies data were obtained by the interview method (45). Questionnaire (9), document (6), scale (4), observation (2) and achievement test (1) were other data collection tools. Since 5 studies were compilation studies, no information was given about data collection tools.

Theresults related to the data analysis methods of the articles examined are given in Chart 7:

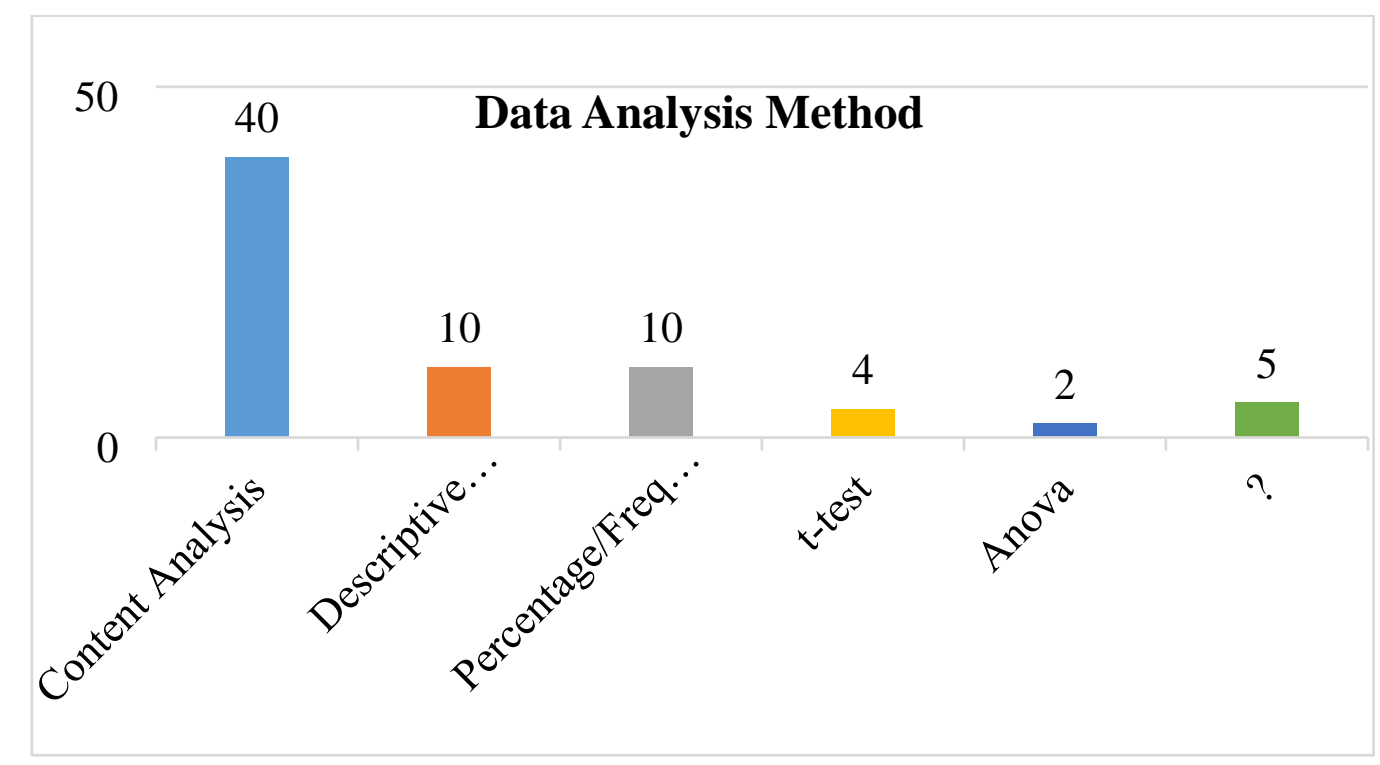

\section{Chart 7. Distribution of Articles' Data Analysis Methods}

When the articles on the problems of teaching Turkish to Syrians are examined, it is seen that content analysis method (40), descriptive analysis (10) and percentage / frequency (10) methods were used for the analysis of the data obtained in most of them. t-Test and Anova 
are the other methods used. In compilation studies (5), there is no information about the data analysis method.

\section{Results Related to Problems Identified in Analyzed Articles}

In this part of the research, the problems identified in the examined articles were classified as; Material Problems,Problems Arising from Language Features of Turkish, Affective Problems, Problems Related to the Teacher, Curriculum Related Problems, Problems Arising from Classroom Management, Problems Related to Learning Areas, Problems Resulting from the Teaching Environment, Problems Related to Family and Environment and presented in tables. In addition, the code of the study in which the problem was given was written in order to reveal the frequency in the tables. Results about the material-related problems experienced in teaching Turkish to Syrians were presented in Table 1:

Table 1. Material Problems in Teaching Turkish to Syrians

\begin{tabular}{lc}
\hline & $f$ \\
\hline Problems related to lack of materials (resource) & 15 \\
Problems related to insufficient books & 10 \\
Problems arising from books not being suitable for the level & 3 \\
Problems arising from the contextual insufficiency of the materials & 2 \\
Problems caused by materials not being suitable for the level & 2 \\
Problems caused by physical inadequacy of books & 2 \\
Problems arising from the lack of a teacher's guide book & 1 \\
\hline
\end{tabular}

In Table 1; there are material-related problems identified in articles prepared to reveal the problems experienced in teaching Turkish to Syrians. According to researches, the biggest problem arising from the material is the lack of material. This problem, which has been found in 15 studies, is followed by these problems; the insufficiency of the books (10), the books' not being suitable for the level (3), the content and physical insufficiency of the available 
materials (2), the materials' not being suitable for the level (2), the physical insufficiency of the books, books' focusing on certain skills (1) and the absence of a teacher's guide book (1).

Results related to the problems arising from the language features of Turkish are given in Table 2:

Table 2. Problems Related to the Language Characteristics of Turkish and Incorrect Learning

\begin{tabular}{lc}
\hline & $f$ \\
\hline Alphabetical difference & 17 \\
Structural differences of Turkish & 11 \\
Misuse of vowels & 4 \\
Confusing letters & 3 \\
Incorrect use of capital letters & 1 \\
Having too many rules & 1 \\
Not using punctuation marks & 1 \\
Misuse of consonants & 1 \\
\hline
\end{tabular}

In the table, it is seen that alphabet difference is the leading problem found to be experienced due to the linguistic characteristics of Turkish and incorrect learning. This problem, identified in 17 studies, is follwed by the structural difference of Turkish (11), misuse of vowels (4), confusion of letters (3), incorrect use of capital letters (1), having too many rules (1), not using punctuation marks (1) and Misuse of consonants (1).

The results of the affective problems experienced in teaching Turkish to Syrians are given in Table 3: 
Anxiety

Prejudice

According to the studies analyzed, the leading affective problem experienced in teaching Turkish to Syrians is the lack of motivation of students. This problem was identified in 12 studies. Students' negative attitude towards Turkish (5) is another important affective problem. Psychological problems (4), resistance to learning Turkish (3), anxiety (3), prejudice (3), fear of losing self-identity (1), and lack of self-confidence (1) are other affective problems.

Results about teacher-related problems in teaching Turkish to Syrians are given in Table 4. 
Not getting specific training

Lack of self-efficacy

Not being aware of the curriculum

Grammar-oriented education

Lack of experience

Non-proficient teachers' teaching Turkish

The biggest teacher-related problem seen in the articles is having inadequate professional knowledge. 20 studies address this problem. Teachers' use of wrong methods and techniques (9), inadequate training of teachers (7), lack of training (3), lack of self-efficacy (2), not being aware of the curriculum (2), giving grammar-oriented education (1), lack of experience (1) and non-proficient teachers' teaching Turkish (1) are other problems related to teachers.

Results about the curriculum problems experienced in teaching Turkish to Syrians are given in Table 5:

Table 5. Curriculum-related Problems in Teaching Turkish to Syrians 
The most important curriculum-related problem identified in the reviewed articles is the inadequate curriculum (9). When the studies are anlyzed, it is seen that this problem is usually put forward by the teachers working in the Turkish / language teaching centers of universities. Teachers who work in schools and public education centers affiliated to the Ministry of National Education generally report that the Turkish Teaching Curriculum or the Course Curriculum of Teaching Turkish for Foreigners published by the Ministry of National Education Lifelong Learning General Directorate is not suitable for the target learners (6). Inadequate duration of the trainings provided (5) is another problem identified in the studies.

Results related to classroom environment problems in teaching Turkish to Syrians are given in Table 6:

Table 6. Problems Caused by the Classroom Environment in Teaching Turkish to Syrians

\begin{tabular}{lc}
\hline & $f$ \\
\hline Disciplinary issues & 11 \\
Unsuitable classrooms for language teaching & 7 \\
Having students with different language levels in the same class & 6 \\
Crowded classrooms & 6 \\
Absenteeism & 5 \\
Use of mother tongue & 4 \\
Classrooms' lack of technological equipment & 2 \\
\hline
\end{tabular}

When 16 studies focusing on the problems arising from classroom environment in teaching Turkish to Syrians are analyzed, these are identified: Disciplinary problems in 11 studies, unsuitable classrooms for language teaching in 7 studies, different language levels in the same class in 6 studies, crowded classrooms in 6 studies, absenteeism in 5 studies, use of mother tongue in 4 studies, lack of technological equipment in classrooms in 2 studies.

Results about the problems related to learning areas in teaching Turkish to Syrians are given in Table 7. 


\begin{tabular}{ll}
\hline & $f$ \\
\hline Pronunciation problems & 14 \\
Not understanding the reading texts & 11 \\
Having difficulty in writing & 10 \\
Grammar problems & 9 \\
Inability to speak fluently & 6 \\
Making spelling mistakes & 6 \\
Inadequate vocabulary & 4 \\
Not understanding listening texts & 4 \\
First reading-writing problems & 2 \\
Using local dialect & 1 \\
\hline
\end{tabular}

When the articles about the problems related to the learning areas encountered in teaching Turkish to Syrians are analyzed; pronunciation problems (14), difficulty in writing (11), not understanding the reading texts (11), grammar problems (9), spelling mistakes (6), inability to speak fluently (5), inadequate vocabulary (4), inability to understand the listening texts (4), problems in first reading and writing (2) and using local dialect (1) are seen.

Results related to the family and environmental problems experienced in teaching Turkish to Syrians are given in Table 8. 


\begin{tabular}{ll}
\hline & $f$ \\
Speaking Arabic in neighbourhood & 6 \\
Indifference & 2 \\
Fear of loss of identity & 2 \\
Negative attitude towards Turkish & 2 \\
Working children & 1 \\
Not cooperating with the school & 1 \\
Not cooperating with the school & 1 \\
\hline
\end{tabular}

When 9 studies focusing on the problems arising from classroom management in teaching Turkish to Syrians are analyzed, speaking Arabic in the neighbourhood in 6 studies, indifference of the family in 2 studies, fear of loss of identity in 2 studies, negative attitude of the family towards Turkish in 2 studies, working children in 1 study, not cooperating with the school in 1 study, and not using Turkish correctly in social media in one study are mentioned.

\section{Conclusion and Discussion}

In this study, which aims to address the problems in teaching Turkish to Syrians with metaanalysis method in the light of relevant articles, the articles were evaluated in terms of sampling, research model, data collection tools, data analysis methods and findings. In this part of the study, the results were discussed in line with the research problems.

Considering the number of authors of the articles analyzed, it is seen that studies with two authors are more prominent, while studies with three or more authors are not preferred. Almost half (33.8\%) of the published studies were published in 2018. Most of the studies (77.4\%) were publicated in Turkish. Looking at the method parts of the researches, it was found that phenomenology $(38.7 \%)$ and case study $(24.1 \%)$ were used as the research model / patter, the experimental model $(4.8 \%)$ was not preferred much.

The samples of the studies were mostly teachers / trainers $(64.5 \%)$. So, it is possible to say that there is not much sample diversity in determining the problems. It is seen that the 
interview method $(70.9 \%)$ was used as a data collection tool in studies. This result shows that there is not much variety in terms of data collection tool. As a data analysis method, it is seen that the content analysis method (62.9\%) was used in most of the studies. When the method parts of the studies are evaluated in general, it is possible to say that the studies are mostly similar to each other and that they do not show much variety. When we look at the results of the studies that mention the problems in teaching Turkish to Syrians, material problems, problems arising from the language characteristics of Turkish, affective problems, problems related to the instructor, curriculum problems, problems related to the teaching environment, problems related to learning areas, family and environmental problems are generally seen in the studies.

One of the problems mentioned in the studies is material problems. Materials are one of the essential elements in teaching Turkish to foreigners and the problems stemming from them affect the teaching process negatively. Thus, problems related to materials are also mentioned in researches. When the literature is examined, related to the material problems in teaching Turkish to Syrians; problems such as lack of materials (Cırıt Karaağaç \& Güvenç, 2019; Duruel, 2016; Gencer, 2017; Gün, 2015a; Phutkaradze \& İnce, 2018); insufficient books, being not suitable for the level or physical inadequacy (Biçer \& Kılıç, 2017; Dilek, et al., 2018; Gün, 2015b; Gün \& Ağırman, 2018); contexual and physical inadequacy of the materials or the unsuitability for the level (Doğan \& Ateş, 2018), the lack of teacher's guide book (Şen \& Solak, 2019), and the books being oriented towards certain skills (Biçer \& K1lıç, 2017) seem to be addressed. Material problems are not the problems we only encounter in teaching Turkish as a foreign language. We also see these problems in the teaching of different languages. Similar problems are observed in the teaching of English as a foreign language to refugees. Deem and Marshall (1980) also stated in their study that problems arise in teaching when the books used in English teaching are not suitable for the level or student characteristics.

Another problem dealt with in the studies is the problems experienced due to the language characteristics of Turkish and students' incorrect learning. Especially if students use a different alphabet or some vowels do not exist in their language, these problems are experienced. When the studies dealing with this subject are analyzed, the problems arising from the language characteristics of Turkish such as alphabetical and structural differences of Turkish (Biçer, 2017; Demirci, 2015; Erdem, 2017; Erdem, Kaya \& Y1lmaz, 2017; Gözübüyük Tamer, 2020; Şengül, 2015; Taşkaya \& Ersoy, 2016); confusion of letters, misuse 
of vowels, and misuse of consonants (Beyhan \& Epçaçan, 2018; Şengül, 2014); misuse of capital letters and not using punctuation marks (Kara, 2010) and having too many rules (Akkaya, 2013) were found. The characteristics of the target language may cause some problems for foreign students learning that language. As a matter of fact, this situation is not only seen in Turkish. David West and Karen (2010) also found in their study that South Korean and North Korean students had problems while learning English due to the language characteristics. Similarly, Deem and Marshall (1980) also stated that refugees from the Indochina region experience problems due to the language characteristics while learning English. The results of the study conducted by Karam, Kibler, and Yoder (2017) on Syrian refugees also support these results. It is one of the results of this study that Syrian refugees who learn English also experience problems due to the language characteristics.

Another problem we encounter in research is affective problems. The emotional feel of the students, the indispensable part of the teaching process, directly affects the language teaching process. While the positive emotions felt by the students affect the process positively, negative emotions inhibit the process. In studies, it was found that problems related to affective problems encountered in teaching Turkish to Syrians such as lack of motivation, having a negative attitude towards Turkish, showing resistance to learning Turkish, experiencing psychological problems, feeling anxious, fear of losing self-identity, being prejudiced and feeling lack of self-confidence (Aydın \& Kaya, 2019; Bozkırlı et al., 2018; Bulut et al., 2018; Erdem, 2016; Gürbüz \& Güleç, 2016; Moralı, 2018; Yıldız, 2016) were stated. Similar results are encountered in English and German teaching. Karam, Kibler, and Yoder (2017) found that refugees experienced lack of self-confidence and this negatively affected language teaching; Koçak and Çobanoğulları (2017) also found that students' attitudes towards language were effective in the success of teaching German.

Another problem dealt with in the studies that touch upon the problems encountered in teaching Turkish to Syrians is the problems caused by teachers. According to the "General Competencies for the Teaching Profession" published by the General Directorate of Teacher Training and Development; (MEB, 2017), teachers are the most vital element of the education system because they are the initiator, developer and practitioner of education. Accordingly, the teacher or instructor, who can be regarded as an indispensable element in language teaching, has a very important place in the teaching of Turkish. Everything that teachers do in the learning process, either positively or negatively, affects the process. The results obtained in the researches are in this direction. According to the studies, the problems related to the 
teacher in teaching Turkish to Syrians can be expressed as; teachers' having inadequate professional knowledge, being not aware of current curriculum, and non-proficient teachers' teaching (Er \& Bayındır, 2015; Erdoğan \& Kana, 2019; Eyüp et al., 2017; Kardeş \& Akman, 2018; Korkmaz, 2018; Pilanc1 et al., 2020; Şahin and Sümer, 2018); teachers' use of wrong methods and techniques, having grammar-focused education, lack of experience and feeling lack of self-efficacy (Gencer, 2017; Taşkaya \& Ersoy, 2016); teachers' getting inadequate training and teachers' not receiving any training (Boylu \& Işık, 2019; Özenç \& Saat, 2019; Özkale \& Yanpar Yelken, 2020; Uğurlu \& Kayhan, 2017; Yaşar \& Amaç, 2018). Similar problems are seen in the teaching of English as a foreign language. Karam, Kibler, and Yoder (2017) also concluded in their research that teachers who do not receive adequate education have problems while teaching English. In language teaching, the teacher's mastery of the professional knowledge, attitude, behaviors, methods-techniques and tools used are very important in learning the target language. As a matter of fact, Baynham (2006) found in his research that students feel more relaxed and learn the language more easily when the teacher is a guide.

Another problem that stands out in the researches is curriculum-based problems. According to the researches, teachers who have Syrian students in their classes mostly express their opinion that Turkish education programs are not suitable for these students, while the instructors working in Turkish / language teaching centers have problems due to the lack of curriculum, and the teachers working in temporary education centers or public education centers report that time is insufficient. According to the studies that address the curriculumbased problems in teaching Turkish to Syrians, these problems are; lack of the curriculum, not being suitable for the target learners, insufficient duration of education and less Turkish course hours (Aykırı, 2017; İmamoğlu \& Çalışkan, 2017; Özer, Komşuoğlu \& Ateşok, 2016). Karam, Kibler, and Yoder (2017) also mention that the lack of a systematic curriculum hinders English teaching.

Another problem stated in the studies is the problems related to the teaching environment. Some of these problems are due to students and some are due to institutions. It is possible to deal with these problems in two ways: Classroom management and learning environment. Problems stemming from classroom management were stated as having disciplinary problems, having students with different language levels in the same class, absenteeism problems and using mother tongue in classrooms (Balkar, Şahin \& Işıklı Babahan, 2016; Taşkaya \& Ersoy, 2016; Taşkın \& Erdemli, 2018), while the problems related 
to the classroom environment were crowded classrooms, physically unsuitable classrooms for language teaching and lack of technological equipments in the classrooms. (Aykır1, 2017; Güven \& İşleyen, 2018; Koçoğlu and Yanpar Yelken, 2018).

Another problem we encounter in studies that address the problems in teaching Turkish to Syrians is the problems experienced in learning areas. The main purpose of teaching Turkish to foreigners is to enable students to express themselves completely and accurately in written and spoken communication and to understand others. From this point of view, problems in language skills or other learning areas will cause students to have problems in expressing themselves. According to the researches, the problems experienced by students in learning areas can be given as follows: having pronunciation problems, being unable to speak fluently, using local dialect, inability to understand listening texts (Akkaya \& Ulum, 2018; Aydın \& Kaya, 2019; Dönmez \& Paksoy, 2015; Erdem, 2016; Erdem, Şengül, Gün \& Büyükaslan, 2015; Yaşar \& Amaç, 2018); inability to understand reading texts, having difficulty in writing, making spelling mistakes, having trouble in first reading and writing (Erdem, 2017; Kara, 2010; Kuzu Jafari, Tonğa \& Kışla, 2018; Solak \& Çelik , 2018; Taşkaya \& Ersoy, 2016; Taşkın \& Erdemli, 2018); problems related to grammar and inadequate vocabulary (Demirci \& Dinçaslan, 2016; Demirgüneş, 2017; Gürbüz \& Güleç, 2016; Kan and Utlu, 2017). There are also problems with learning areas in the teaching of different languages. It was found that there are grammatical problems in teaching English as a foreign language or that students have difficulty in speaking skills (David-West \& Karen, 2010). Problems in learning areas can be solved by using different methods and techniques. For example, studies have shown that some problems in writing skill can be overcome by using process-based writing methods (Öztürk \& Alan, 2019, 2020).

The last problem we encounter in studies focusing on the problems encountered in teaching Turkish to Syrians is the problems related to the family and the environment. While learning a foreign language, the family and the environment are as important as the teacher, student, material and learning environment. Because family and environment are the influential factors on the motivation of the student as well as on the frequency of using the target language. In the researches, the family and environmental problems experienced by Syrian students who learn Turkish were mentioned. These problems are speaking Arabic in daily life (Boylu and Işık, 2020; Güngör \& Şenel, 2018; Şimşir \& Dilmaç, 2018); indifference, fear of loss of identity, negative attitude of family towards Turkish, working children, family 
not cooperating with school (Tanrıkulu, 2017) and misuse of Turkish in social media (Ünal et al., 2018).

As a result of the results obtained from the researches analyzed, the following suggestions can be given about the problems experienced in teaching Turkish to Syrians:

- It is seen that most of the investigated studies are aimed at identifying the problems. Research can also be done to solve problems.

- According to studies, there are problems in terms of materials in teaching Turkish to Syrians. It is necessary to prepare materials for the target learners and to eliminate the deficiencies of the existing materials.

- At the root of the problems experienced by teachers / instructors who teach Turkish to Syrians, it is generally seen that they do not have professional knowledge in teaching Turkish to foreigners. In order to stop the other problems to continue increasingly, this problem should be eliminated and the instructors should be provided with the necessary training and education.

- There are problems due to the linguistic features of Turkish. These problems should be minimized by changing the strategies, methods and techniques used while teaching Turkish.

- Considering that there is no suitable curriculum for Syrians or that the curriculum used is not efficient, it is necessary to develop programs or curriculum suitable for the target groups.

- Researchers should be supported to conduct experimental research to solve the problems detected.

Ethical Approval: Since this research is a Meta-Analysis study, ethics committee approval was not obtained.

Conflict Interest: The author declare that he has no conflict of interest.

Authors Contributions: Contribution to the preparation and revision of the article was made by the relevant author. 


\section{References $^{1}$}

Açık, F. (2008, March). Türkiye'de yabancılara Türkçe öğretilirken karşılaşılan sorunlar ve çözüm önerileri. Uluslararası Türkçe Ĕ̆itimi ve Öğretimi Sempozyumu, sunulmuş bildiri, Doğu Akdeniz Üniversitesi Eğitim Fakültesi Türkçe Eğitimi Bölümü.

*Akkaya, A. (2013). Suriyeli mültecilerin Türkçe algıları. EKEV Akademi Dergisi, 17(56), 179-190.

*Akkaya, A. \& Ulum, Ö. G. (2018). Yabancı dil olarak Türkçe öğrenen Suriyeli sığınmacıların dil öğrenmeye ilişkin inançları. International Journal of Languages' Education and Teaching, 6(4), 1-11.

Alyılmaz, C. (2010). Türkçe öğretiminin sorunları. Turkish Studies, 5(3), 728-749.

*Aydın, H. \& Kaya, Y. (2019). Education for Syrian Refugees: The New Global Issue Facing Teachers and Principals in Turkey. Educational Studies, 55(1), 46-71. doi:10.1080/00131946.2018.1561454

*Aykırı, K. (2017). Sınıf Öğretmenlerinin Sınıflarındaki Suriyeli Öğrencilerin Eğitim Durumlarına İlişkin Görüşleri. Turkish Journal of Primary Education, (2), 44-56.

*Balkar, B., Şahin, S. \& Işıklı Babahan, N. (2016). Geçici eğitim merkezlerinde (GEM) görev yapan Suriyeli öğretmenlerin karşılaştıkları Sorunlar. Eğitimde Kuram ve Uygulama, 12(6), 1290-1310.

Baynham, M. (2006). Agency and contingency in the language learning of refugees and asylum seekers. Linguistics and Education, 17(1), 24-39. doi:10.1016/j.linged.2006.08.008

*Beyhan, D. \& Epçaçan, C. (2018). Suriyeli öğrencilerin Türk eğitim sistemine entegrasyonu projesi kapsamında geçici eğitim merkezlerinde görev yapan dil öğreticilerinin dil öğretirken karşılaştıkları sorunlar ve çözüm önerileri. Turkish Studies, 13(19), 285306. doi:10.7827/TurkishStudies. 14040

Biçer, N. (2012). Hunlardan günümüze yabancılara Türkçe öğretimi. Uluslararası Türkçe Edebiyat Kültür Eğitim Dergisi, 1(4), 107-133.

\footnotetext{
${ }^{1}$ Articles analyzed within the scope of the research are marked with *
} 
*Biçer, N. (2017). The Views of Syrian Refugees Migrating to Turkey on the Turkish Language and Culture: Kilis Case. Journal of Education and Training Studies, 5(3), 97-109. doi:10.11114/jets.v5i3.2100

Biçer, N. \& Alan, Y. (2019). Türk soylulara Türkçe öğretimi ile ilgili çalışmalara genel bir bakış. Fırat Üniversitesi Sosyal Bilimler Dergisi, 29(1), 143-157.

*Biçer, N. \& Kılıç, B. S. (2017). Suriyeli Öğrencilere Türkçe Öğretmek İçin Kullanılan Ders Kitaplarının Öğretmen Görüşleri Doğrultusunda Değerlendirilmesi. Ana Dili Eğitimi Dergisi, 5(4), 649-663. doi:10.16916/aded.329809

*Boylu, E. \& Işık, P. (2019). Suriyeli Mülteci Çocuklara Yabancı Dil Olarak Türkçe Öğretenlerin Yaşadıkları Durumlara İlişkin Görüşleri. GEFAD / GUJGEF, 39(2), 895936. doi:10.17152/gefad.421069

*Boylu, E. \& Işık, P. (2020). Suriyeli mültecilerin yoğun olarak yaşadığı illerde Türkçe öğrenme süreçleri üzerine öğretmen görüşleri. Bolu Abant İzzet Baysal Üniversitesi Eğitim Fakültesi Dergisi, 20(2), 1113-1128.

*Bozkırlı, K. Ç., Er, O. \& Alyılmaz, S. (2018). Teacher opinions-based evaluation of problems in Turkish instruction to Syrians. European Journal of Foreign Language Teaching, 3(2), 130-147. doi:10.5281/ZENODO.1251566

*Bulut, S., Kanat Soysal, Ö. \& Gülçiçek, D. (2018). Suriyeli öğrencilerin Türkçe öğretmeni olmak: Suriyeli öğrencilerin eğitiminde karşılaşılan sorunlar. Uluslararası Türkçe Edebiyat Kültür Eğitim Dergisi, 7(2), 1210-1238.

Burak, D. \& Amaç, Z. (2020). Mültecilerin ilkokuldaki eğitimi ve sınıf öğretmenleri için etkinlik örnekleri. M. A. Karaman, Z. Amaç, Y. Doğan ve F. Bektaş (Ed.), Panik Yok!!! Ben Mülteciyim içinde (2. bs.). Ankara: Vizetek Yayıncılık.

Candaş Karababa, Z. C. (2009). Yabancı dil olarak Türkçenin öğretimi ve karşılaşılan sorunlar. Ankara Üniversitesi Ĕ̈itim Bilimleri Fakültesi Dergisi, 42(2), 265-277.

*Cırıt Karaağaç, F. \& Güvenç, H. (2019). Resmi ilkokullara devam eden Suriyeli mülteci öğrencilerin eğitim sorunları. OPUS Uluslararası Toplum Araştırmaları Dergisi, 11(18), 530-568. doi:10.26466/opus.530733

Çalık, M. \& Sözbilir, M. (2014). İçerik analizinin parametreleri. Eğitim ve Bilim, 39(174), 3338 . 
David-West, A. \& Karen, C. (2010). Teaching English to North Korean refugees in South Korea: an interview with Karen Choi. North Korean Review, 6(1), 108-119. doi:10.3172/NKR.6.1.108

Deem, M. J. \& Marshall, W. J. (1980). Teaching a second language to Indochinese refugees when no program exists. International Literacy Association, 23(7), 601-605.

*Demirci, M. (2015). B1 seviyesinde Türkçe öğrenen Suriyeli öğrencilerin sesli okuma becerisiyle ilgili tespitler. Turkish Studies, 10(7), 333-358. doi:10.7827/TurkishStudies.8149

*Demirci, M. \& Dinçaslan, M. F. (2016). The use of valence of Syrian students learning Turkish as a foreign language. Eğitimde Kuram ve Uygulama, 12(5), 1011-1040.

Demirel, Ö. \& Şahinel, M. (2006). Türkçe ve sınıf ögretmenleri için Türkçe öğretimi (7. bs.). Ankara: Pegem Akademi.

*Demirgüneş, S. (2017). Microstructural (cohesion and coherence) text generation problems of Syrian refugee students learning Turkish. Universal Journal of Educational Research, 5(4), 581-590. doi:10.13189/ujer.2017.050407

*Dilek, Ş., Boyaci, B. \& Yaşar, E. (2018). Teaching Turkish as a second language to Syrian refugees. Educational Research and Reviews, 13(18), 645-653. doi:10.5897/ERR2018.3565

*Doğan, B. \& Ateş, A. (2018). Evaluation of Turkish language teaching for Syrian students who are learned in monetary schools by teachers (Malatya Sample). Çocuk, Edebiyat ve Dil Ë̆itimi Dergisi, 1(1), 105-124.

*Dönmez, M. I. \& Paksoy, S. (2015). Türkiye'de öğrenim gören Suriyeli öğrencilerin Türkçe öğrenmede karşılaştıkları sorunlar üzerine bir araştırma: Kilis 7 Aralık Üniversitesi örneği. International Journal of Languages' Education, 1907-1919. doi:10.18298/ijlet.366

Durmuş, M. (2013). Türkçenin yabancılara öğretimi: Sorunlar, çözüm önerileri ve yabancılara Türkçe öğretiminin geleceğiyle ilgili görüşler. Adlyaman Üniversitesi Sosyal Bilimler Enstitüsü Dergisi Türkçenin Eğitimi Öğretimi Özel Sayısl, 6(11), 207-228.

*Duruel, M. (2016). Suriyeli sığınmacıların eğitim sorunu. Atatürk Üniversitesi İktisadi ve İdari Bilimler Dergisi, 30(5), 1399-1414. 
*Er, A. R. \& Bayındır, N. (2015). Pedagogical approaches of elementary teachers for prımary refugee children. International Journal of Social and Educational Sciences, 2(4), 175185.

Er, O., Biçer, N. \& Bozkırlı, K. Ç. (2012). Yabancılara Türkçe öğretiminde karşılaşılan sorunların ilgili alan yazını ışığında değerlendirilmesi. Uluslararası Türkçe Edebiyat Kültür Ĕ̈itim Dergisi Sayı, 1(2), 51-69.

*Erdem, C. (2017). Sınıfında mülteci öğrenci bulunan sınıf öğretmenlerinin yaşadıkları öğretimsel sorunlar ve çözüme dair önerileri. Medeniyet Ĕ̆itim Araştırmaları Dergisi, $1(1), 26-42$.

*Erdem, M. D. (2016). Instructors' opinions about the education on Turkish speaking abilities of Syrian students. the anthropologist, 24(2), 541-550. doi:10.1080/09720073.2016.11892048

*Erdem, M. D., Kaya, İ. \& Yılmaz, A. (2017). Örgün eğitim kapsamındaki Suriyeli çocukların eğitimleri ve okul yaşantıları hakkında öğretmen görüşlerinin değerlendirilmesi. International Journal of Languages' Education and Teaching, 5(3), 463-476

*Erdem, M. D., Şengül, M., Gün, M. \& Büyükaslan, A. (2015). Tekerleme alıştırmalarına dayalı etkinliklerin Türkçeyi yabancı dil olarak öğrenen Suriyeli Arapların konuşma becerilerine etkisi. Route Educational and Social Science Journal, 2(2), 1-11. doi:10.17121/ressjournal.322

*Erdoğan, D. \& Kana, F. (2019). Yaygın eğitim kurumlarında yabancılara Türkçe öğreten öğretmenlerin "Yabancı Diller Türkçe A1 Seviyesi Kurs Programını" uygulama süreci. International Journal of Languages' Education and Teaching, 7(4), 49-74.

*Eyüp, B., Aslan, N. \& Cevher, T. Y. (2017). Mültecilere Türkçenin yabancı dil olarak öğretilmesine yönelik uyum kursuna katılan öğreticilerin kurs hakkındaki görüşleri ve hazır bulunuşluk durumları. International Journal of Languages' Education, 5(4), 174-200. doi:10.18298/ijlet.2423

*Gencer, T. E. (2017). Göç ve eğitim ilişkisi üzerine bir değerlendirme: Suriyeli çocukların eğitim gereksinimi ve okullaşma süreçlerinde karşılaştıkları güçlükler. Journal of International Social Research, 10(54), 838-851. doi:10.17719/jisr.20175434652 
*Gözübüyük Tamer, M. (2020). Mülteci ve sığınmacı yetişkinlere sunulan Türkçe dil öğretiminin halk eğitim merkezi öğretmenleri tarafından değerlendirilmesi (Trabzon örneği). Karadeniz Araştırmalarl, 17(65), 97-115.

*Gün, M. (2015a). The opinions of the instructors about the listening skills of Syrian students learning Turkish. International Journal of Social Sciences and Education, 1(4), 559569.

* Gün, M. (2015b). Yabancılara Türkçe öğretimi veren elemanların Adıyaman ili çadır kent bölgesinde Türkçe öğrenen Suriyeli Araplara Türk kültürü aktarımına ilişkin görüşleri. Cappadocia Journal of History and Social Sciences, 1(5), 119-138. doi:10.18299/cahij.61

*Gün, M. \& Ağırman, F. (2018). Öğretim elemanlarının Türkçe öğrenen Suriyeli Arap öğrencilere dil bilgisi öğretimine yönelik görüşleri. Çukurova Araştırmaları Dergisi, 4(2), 101-116. doi:10.18560/cukurova.1106

*Güngör, F. \& Şenel, E. A. (2018). Yabancı uyruklu ilkokul öğrencilerinin eğitim öğretiminde yaşanan sorunlara ilişkin öğretmen ve öğrenci görüşleri. Journal of Educational Sciences International, 8(2), 124-173.

*Gürbüz, R. \& Güleç, İ. (2016). Türkiye'de eğitim gören yabanc1 öğrencilerin Türkçeye ilişkin görüşleri: Sakarya Üniversitesi örneği. Sakarya University Journal of Education, 6(2), 141-153. doi:10.19126/suje.18712

*Güven, S. \& İşleyen, H. (2018). Sınıf yönetiminde iletişim, iletişim engelleri ve Suriyeli öğrenciler. International Journal of Social Humanities Sciences Research (JSHSR), 5(23), 1293-1308. doi:10.26450/jshsr.485

*Imamoğlu, H. V. \& Çalışkan, E. (2017). Yabancı uyruklu öğrencilerin devlet okullarında ilkokul eğitimine dair öğretmen görüşleri: Sinop ili örneği. Karabük Üniversitesi Sosyal Bilimler Enstitüsü Dergisi, 7(2), 529-546. doi:10.14230/joiss454

*Kan, M. O. \& Utlu, G. (2017). Errors in case markers made by Syrian students who learn Turkish in temporary education center. Journal of Education and Training Studies, 5(9), 205-212. doi:10.11114/jets.v5i9.2562

*Kara, M. (2010). Gazi Üniversitesi TÖMER öğrencilerinin Türkçe öğrenirken karşılaştıkları sorunlar ve bunların çözümüne yönelik öneriler. Türk Eğitim Bilimleri Dergisi, 8(3), 661-696. 
Karam, F. J., Kibler, A. K. \& Yoder, P. J. (2017). "Because even us, Arabs, now speak English": Syrian refugee teachers' investment in English as a foreign language. International Journal of Intercultural Relations, 60, 169-182. doi:10.1016/j.ijintrel.2017.04.006

*Kardeş, S. \& Akman, B. (2018). Suriyeli mültecilerin eğitimine yönelik öğretmen görüşleri. İlköğretim Online, 17(3), 1224-1237. doi:10.17051/ilkonline.2018.466333

Koçak, M. \& Çobanoğulları, F. (2017). Dünyada ikinci yabancı dil olarakAlmanca öğretiminde Danimarka örneği. Uluslararası Eğitim Bilimleri Dergisi, 1(1), 1-12.

*Koçoğlu, A. \& Yanpar Yelken, T. (2018). Suriyeli öğrencilere Türkçe dil becerileri kazandırma sürecinde ilkokul Türkçe dersi öğretim programları ile ilgili öğretmen görüşleri. Journal of Qualitative Research in Education, 6(2), 131-160. doi:10.14689/issn.2148-2624.1.6c2s $7 \mathrm{~m}$

*Korkmaz, E. (2018). Yabancılara Türkçe öğretiminde yaşanan bazı sorunlar ve çözüm önerileri. KSÜ Sosyal Bilimler Dergisi, 15(1), 89-104.

*Kuzu Jafari, K., Tonğa, N. \& Kışla, H. (2018). Suriyeli öğrencilerin bulunduğu sınıflarda görev yapan sınıf öğretmenlerinin görüşleri ve uygulamaları. Academy Journal of Educational Sciences, 2(2), 134-146. doi:10.31805/acjes.479232

Miles, M. B. \& Huberman, M. A. (1994). Qualitative data analysis. London: Sage Publication.

*Moralı, G. (2018). Suriyeli mülteci çocuklara Türkçenin yabancı dil olarak öğretiminde karşılaşılan sorunlar. OPUS Uluslararası Toplum Araştırmaları Dergisi, 8(15), 14261449. doi:10.26466/opus. 443945

Okur, A. (2013). Yabancılara Türkçe öğretiminde karşılaşılan sorunlara yönelik inceleme. The Journal of Academic Social Science Studies, 6(6), 877-892. doi:10.9761/JASSS1648

MEB (2017). Öğretmenlik mesleği genel yeterlilikleri. Öğretmen Yetiştirme ve Geliştirme Genel Müdürlüğü: Ankara.

*Özenç, E. G. \& Saat, F. (2019). Sınıf Öğretmenlerinin Suriyeli öğrencilerin eğitiminde karşılaştığ1 sorunlar. International Journal of Active Learning, 4(2), 60-74. 
*Özer, Y. Y., Komşuoğlu, A. \& Ateşok, Z. Ö. (2016). Türkiye'deki Suriyeli çocukların eğitimi: sorunlar ve çözüm önerileri. Akademik Sosyal Araştırmalar Dergisi, 4(37), 76-110.

*Özkale, U. \& Yanpar Yelken, T. (2020). Analysis of problems encountered by instructors teaching Turkish as a foreign language to Syrian children and their opinions on their participation in the certification program for teaching Turkish as a foreign language. Journal of Language and Linguistic Studies, 16(1), 185-212.

*Öztürk, J. \& Alan, Y. (2019). 4+1 Planlı yazma ve değerlendirme modelinin Türkçeyi yabancı dil olarak öğrenen öğrencilerin yazma becerilerine etkisi. Mustafa Kemal Üniversitesi Sosyal Bilimler Enstitüsü Dergisi, 16(44), 221-250.

*Öztürk, J. \& Alan, Y. (2020). Yabancı öğrencilerin bağdaşıklık araçlarını kullanma düzeylerinde $4+1$ planlı yazma ve değerlendirme modelinin etkisi. Uluslararası Türkçe Edebiyat Kültür Ĕ̌gitim Dergisi, 9(1), 293-315.

*Phutkaradze, M. \& İnce, B. (2018). Yabancı dil olarak Türkçe öğretiminde yeni bir hedef kitle: düzensiz göçmenler. Turkophone, 5(1), 24-40.

*Pilancı, H., Çalışır Zenci, S., Saltık, O. \& Yaşar, S. (2020). HEM'lerde Suriyeliler'e Türkçe öğreten öğretmenler üzerine bir araştırma. Dil Eğitimi ve Araştırmaları Dergisi, 6(1), 127-144. doi:10.31464/jlere.672475

*Solak, E. \& Çelik, S. (2018). Türkiye'de eğitim gören mülteci öğrencilerin dilsel sorunlarının incelenmesi. Uluslararası Sosyal Araştırmalar Dergisi, 11(57), 425-432. doi:10.17719/jisr.2018.2461

*Şahin, S. \& Sümer, S. (2018). The problems experienced in the integration process of Syrian students into the Turkish education system. Universal Journal of Educational Research, 6(5), 909-918. doi:10.13189/ujer.2018.060512

*Şen, F. \& Solak, E. (2019). Öğretici görüşlerine göre sı̆̆ınmacı öğrencilere Türkçe öğretiminde karşılaşılan sorunların değerlendirilmesi: Kayseri ili örneği. International Journal of Language Academy, 7(4), 349-360. doi:10.29228/ijla.25856

*Şengül, K. (2014). Türkçenin yabancı dil olarak öğretiminde alfabe sorunu. Uluslararası Türkçe Edebiyat Kültür Eğitim Dergisi, 3(1), 325-339. 
*Şengül, M. (2015). The opinions of instructors teaching Turkish to foreigners about the writing skills of Syrian students. Journal of Education and Training Studies, 3(5), 177 186.

*Şimşir, Z. \& Dilmaç, B. (2018). Yabancı uyruklu öğrencilerin eğitim gördüğü okullarda öğretmenlerin karşılaştığı sorunlar ve çözüm önerileri. İlköğretim Online, 17(3), 17191737. doi:10.17051/ilkonline.2018.466425

*Tanrıkulu, F. (2017). Türkiye'de yaşayan Suriyeli çocukların eğitim sorunu ve çözüm önerileri. Liberal Düşünce Dergisi, 22(86), 127-144.

*Taşkaya, M. \& Ersoy, G. (2016). Suriyeli sığınmacılara Türkçe öğretiminde sınıf öğretmenlerinin uygulamaları. Çukurova Araştırmaları Dergisi, 2(1), 130-138. doi:10.18560/cukurova.31

*Taşkın, P. \& Erdemli, Ö. (2018). Education for Syrian refugees: problems faced by teachers in Turkey. Eurasian Journal of Educational Research, (75), 155-178.

*Tunga, Y., Engin, G. \& Çağıltay, K. (2020). Türkiye'deki Suriyeli çocukların eğitiminde karşılaşılan sorunlar üzerine bir alanyazın taraması. Inönü Üniversitesi Eğitim Fakültesi Dergisi, 21(1), 317-333. doi:10.17679/inuefd.535845

Türkben, T. (2018). Yabancı dil olarak Türkçe öğretimi alanında yapılan lisansüstü çalışmaların değerlendirilmesi. Uluslararası Türkçe Edebiyat Kültür Eğitim Dergisi, 7(4), 2464-2479.

*Uğurlu, N. I. \& Kayhan, N. (2017). Teacher opinions on the problems faced in reading and writing by Syrian migrant children in their first class at primary school. Journal of Education and Learning, 7(2), 76. doi:10.5539/jel.v7n2p76

*Ünal, K., Taşkaya, S. M. \& Ersoy, G. (2018). Suriyeli göçmenlerin yabancı dil olarak Türkçe öğrenirken karşılaştıkları sorunlar ve çözüm önerileri. Ahi Evran Üniversitesi Sosyal Bilimler Enstitüsü Dergisi, 4(2), 134-149.

*Yaşar, M. R. \& Amaç, Z. (2018). Teaching Syrian students in Turkish schools: experiences of teachers. Sustainable Multilingualism, 13(1), 225-238. doi:10.2478/sm-2018-0019

*Yıldız, N. (2016). Yabancılara Türkçe öğretiminde okuma öğretimi yöntemlerinin okuduğunu anlamaya etkisi. Recep Tayyip Erdoğan Üniversitesi Sosyal Bilimler Dergisi, 2(3), 98-112. 